\title{
PORTUGUESE GRANITES ASSOCIATED WITH Sn-W AND Au MINERALIZATIONS
}

\begin{abstract}
ANA M. R. NEIVA
NEIVA, ANA M.R. 2002. Portuguese granites associated with Sn-W and Au mineralizations. Bulletin of the Geological Society of Finland 74, Parts 1-2, 79101.

In northern and central Portugal, there are different tin-bearing granites. Most of them are of S-type, others have mixed characteristics of I-type and S-type granites and a few are of I-type. Tin-tungsten deposits are commonly associated with Hercynian tin-bearing S-type granites. Some quartz veins with wolframite are associated with an I-type granite, which has a low Sn content. In suites of tin-bearing S-type granitic rocks, Sn content increases as a function of the degree of fractional crystallization. Greisenizations of two-mica S-type granites associated with tin-tungsten mineralizations are accompanied by an increase in $\mathrm{SiO}_{2}, \mathrm{H}_{2} \mathrm{O}^{+}, \mathrm{Sn}, \mathrm{W}, \mathrm{Nb}, \mathrm{Ta}, \mathrm{Rb}, \mathrm{Zn}$, and $\mathrm{Pb}$ and decrease in $\mathrm{MgO}, \mathrm{Na}_{2} \mathrm{O}, \mathrm{V}, \mathrm{Sc}$, $\mathrm{Zr}$, and $\mathrm{Sr}$. The granite associated with the Jales gold deposit is of S-type and strongly differentiated like the tin-bearing S-type granites, but it has a very low $\mathrm{Sn}$ content. During fractional crystallization, $\mathrm{Si}, \mathrm{Rb}, \mathrm{Sn}, \mathrm{Pb}, \mathrm{Au}, \mathrm{As}, \mathrm{Sb}$, and $\mathrm{S}$ increase. During increasing degree of hydrothermal alteration of this granite at the gold-quartz vein walls, there are progressive increases in $\mathrm{K}_{2} \mathrm{O}, \mathrm{H}_{2} \mathrm{O}^{+}, \mathrm{Sn}$, $\mathrm{Cs}, \mathrm{Cu}, \mathrm{Pb}, \mathrm{Au}, \mathrm{Sb}, \mathrm{As}$, and $\mathrm{S}$.
\end{abstract}

Key words: granites, tin ores, tungsten ores, gold ores, quartz veins, greisenization, hydrothermal alteration, Portugal

Ana M.R. Neiva: Department of Earth Sciences, University of Coimbra, 3000272 Coimbra, Portugal

E-mail: neiva@ci.uc.pt 


\section{INTRODUCTION}

Tin and tungsten primary deposits are the result of hydrothermal systems commonly related to magmatic rocks of granitic composition. These hydrothermal systems are developed in apical highlevel portions of granites. Tin and tungsten accumulate in the residual melts during fractional crystallization. Magmatic cassiterite has been locally found in granites (Haapala 1997). The tin deposits are related to tin granites, which are two to twenty times richer in Sn than ordinary granites due to magmatic fractionation of source magmas with two to three times more Sn than average crustal abundance and ordinary granites (Lehmann 1987, Heinrich 1990, Solomon et al. 1994). Unaltered tin-bearing granites contain 18-26 ppm Sn (Lehmann 1990) and $7 \pm 3 \mathrm{ppm} \mathrm{W}$ (Tischendorf 1974).

Tin potential in a granite is developed by magmatic fractional crystallization and it is well shown in the granite-aplite-pegmatite sequence (e.g., Neiva 1975), or by greisenization (e.g., Neiva 1974), which results from the interaction of residual Sn-rich fluids, separated from the crystallizing magma, with some parts of the cooling granite. Commonly greisenization occurs after fractional crystallization, and $\mathrm{Sn}$ enrichment is higher during greisenization (e.g., Schwartz \& Askury 1989).Tin is mined from pegmatites, greisens and quartz veins.

Wolframite does not occur in granites, but it crystallizes in greisenized granites and quartz veins.

Granodiorite and granite are not commonly regarded as potential hosts for gold mineralizations (e.g., Blevin \& Chappell 1992). However, gold mineralization is hosted by granitic rocks (e.g., Cotelo Neiva \& Neiva 1990, Neiva 1992, Newberry et al. 1995, McCoy et al. 1997, Cole et al. 2000). Gold enrichment during fractionation was documented in the Jales area, Portugal (Neiva 1992) and Fairbanks district of Alaska (McCoy et al. 1997), where the Jales gold deposit and Fort Knox gold deposit occur, respectively. The granitic rocks from both areas contain ilmenite, and consequently the respective magmas have low $\mathrm{f}_{\mathrm{O}_{2}}$.
Magmatic-hydrothermal processes are responsible for the deposition of gold mainly in quartz veins in both deposits.

Some granodiorite- and granite-related gold deposits occur in areas of intrusion-related tungstentin mineralization and they have a metal association similar to the tungsten-tin deposits, suggesting a magmatic-hydrothermal origin (Thompson et al. 1999).

In this paper, the magmatic characteristics of granites associated with Portuguese tin-tungsten deposits and a gold deposit are discussed, as well as the hydrothermal alterations of those granites.

\section{PORTUGUESE GRANITES ASSOCIATED WITH TIN AND TUNGSTEN DEPOSITS}

Hercynian granites predominate in northern and central Portugal (Fig. 1) and are associated with tin and tungsten deposits. Cassiterite occurs mainly in granitic pegmatites, quartz veins (Fig. 2a) and greisenized granites; it is also found in small amounts in some aplites and locally in granite. Wolframite (Fig. 2b) and scheelite occur mainly in quartz veins, but scheelite is also found in skarns produced by granite metasomatism on magnesian marbles. Cassiterite and wolframite commonly occur in the same quartz veins. Cassiterite is associated with muscovite selvages, particularly along vein-schist contacts, and wolframite is distributed throughout the veins.

There are many occurrences of cassiterite and wolframite in northern and central Portugal (Cotelo Neiva 1944) and most of them have been exploited. The most intense period of exploitation of Sn and W deposits in Portugal took place from 1939 to 1958 , corresponding mainly to two periods (1939-1943, the Second World War, and 1951-1952, the Korean War). About 40000 tons of cassiterite and 69249 tons of wolframite were exploited (Carneiro, 1959). In Portugal, today only Panasqueira mine is operating, but with a low exploitation. 


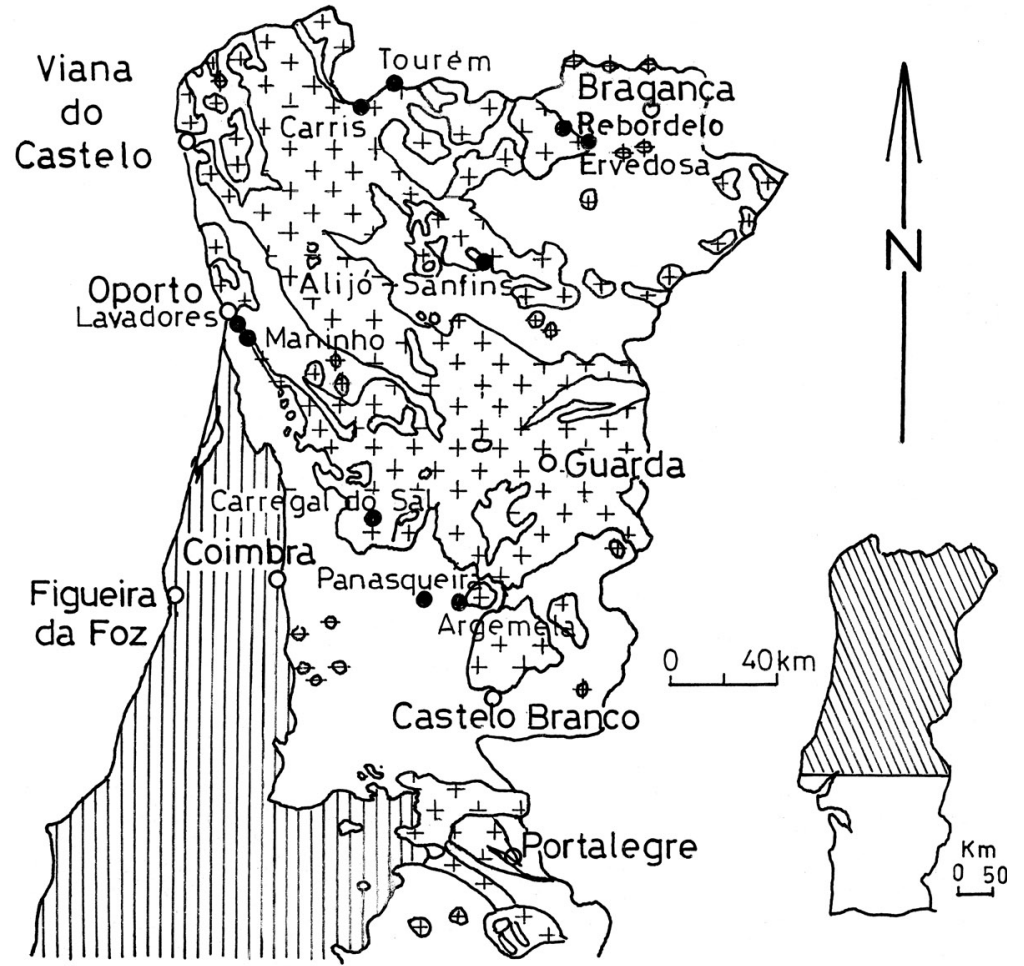

IIII Mesozoic and Cenozoic sedimentary rocks

${ }^{+}+^{+}$Hercynian granitic rocks

Pre-Ordovician metamorphic complexes,

Paleozoic and some basic and ultrabasic rocks
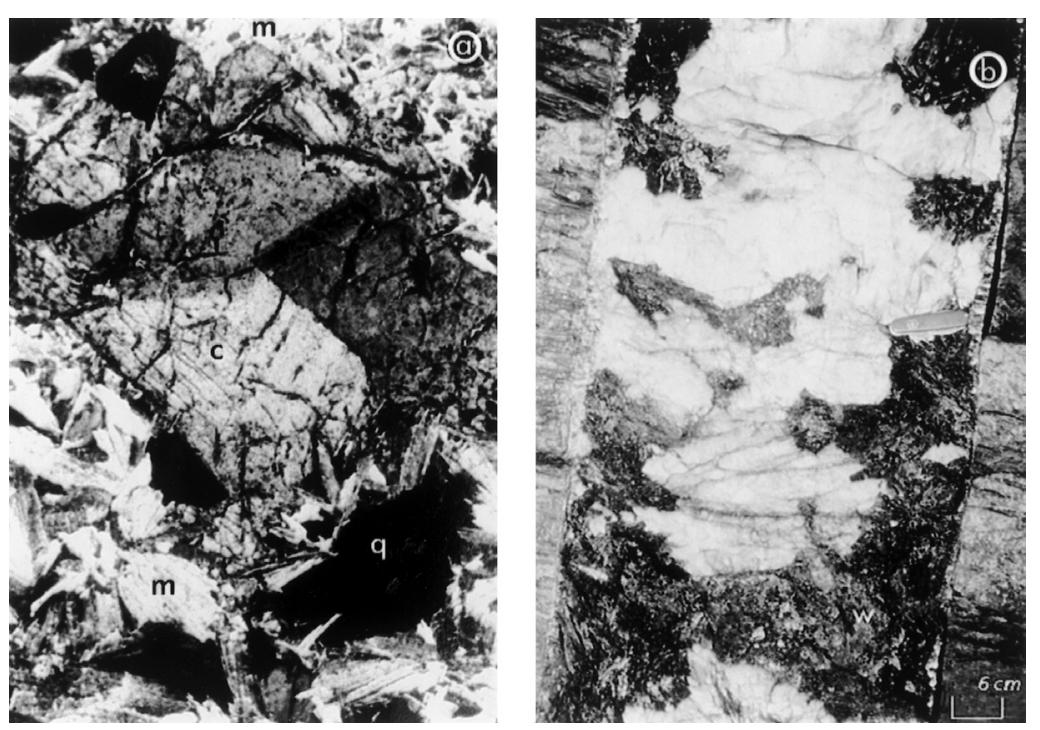

Fig. 1. Simplified geological map of northern and central Portugal.

Fig. 2. a) Euhedral crystal of cassiterite (c) from the quartz veins at Argozelo, associated with a muscoviterich selvage $(m)$ and quartz. (q) (x27). b) Wolframite (w) in a $50 \mathrm{~cm}$ wide quartz vein at Panasqueira. 


\section{MAGMATIC CHARACTERISTICS OF PORTUGUESE TIN-BEARING GRANITES}

\section{Two-mica granites and muscovite granites}

In general, Portuguese unaltered tin-bearing granites of S-type (derived by partial melting of metasedimentary materials) have 18-100 ppm Sn and 3-9 ppm W (Cotelo Neiva 1972, Neiva 1973, 1983, 1984, 1993, 1994, Roger et al. 1980, Silva \& Neiva 1990, 2000, Neves 1991, 1997, Gomes 1996, Ramos 1998, Gomes \& Neiva 2002). However, higher Sn contents were found, up to 220 ppm in a muscovite granite from Viseu (Roger et al. 1980) and 519-806 ppm in the Argemela microgranite (Charoy \& Noronha 1996). They are either syn- to late-tectonic or post-tectonic two-mica granites, with primary muscovite usually prevailing over $\mathrm{Fe}^{2+}$-biotite, or muscovite granites. However, some two-mica granites have more biotite than muscovite (Silva \& Neiva 2000). The granites contain ilmenite and are characterized by $\mathrm{f}_{\mathrm{O}_{2}}$ generally lower than that of Ni-NiO buffer. They are peraluminous with $\mathrm{A} / \mathrm{CNK}$ [molecular $\mathrm{Al}_{2} \mathrm{O}_{3}$ / $\left.\left(\mathrm{CaO}+\mathrm{Na}_{2} \mathrm{O}+\mathrm{K}_{2} \mathrm{O}\right)\right] \geq 1.1$, strongly differentiated, enriched in $\mathrm{Rb}, \mathrm{Cs}, \mathrm{Li}, \mathrm{F}$, and LREE with respect to $\operatorname{HREE}\left(\mathrm{La}_{\mathrm{N}} / \mathrm{Yb}_{\mathrm{N}}=8-43\right)$, improverished in $\mathrm{Ti}$, $\mathrm{Cr}, \mathrm{V}, \mathrm{Ni}, \mathrm{Co}, \mathrm{Sr}$, and $\mathrm{Ba}$ (Table 1 and analyses 1a and $2 \mathrm{a}$ of Table 3, Fig. 3) and have a negative Eu anomaly with Eu/Eu* of $0.20-0.43$ (Fig. 4a). They are 336-287 Ma old, as determined by whole-rock $\mathrm{Rb}-\mathrm{Sr}$ isochrons, and have initial ${ }^{87} \mathrm{Sr} /$ ${ }^{86} \mathrm{Sr} \geq 0.708$ (Neiva 1993, 1994, Almeida et al. 1995, Silva 1995, Gomes 1996, Gomes \& Neiva 2000, 2002), $\varepsilon_{\mathrm{Nd}}(\mathrm{T})$ ranging from -4.5 to -16.4 (Almeida et al. 1995, Silva 1995, Gomes 1996, Silva \& Neiva 2000) and $\delta^{18} \mathrm{O}$ from 11.0 to $12.8 \%$ (Neves 1991, Ramos 1998).

Generally these tin-bearing granites have S-type petrographic and mineralogical characteristics and their contents of major and trace elements and values of initial ${ }^{87} \mathrm{Sr} /{ }^{86} \mathrm{Sr}$ are similar to the S-type granites from the Lachlan Fold Belt (LFB), Australia (Chappell \& White 1992), but $\varepsilon_{\mathrm{Nd}}(\mathrm{T})$ ranges to lower values. Furthermore, the high $\mathrm{Zn}$ content in the muscovite granite from Ervedosa (Table 1 , analysis 6 ) is attributed to strong fractionation.

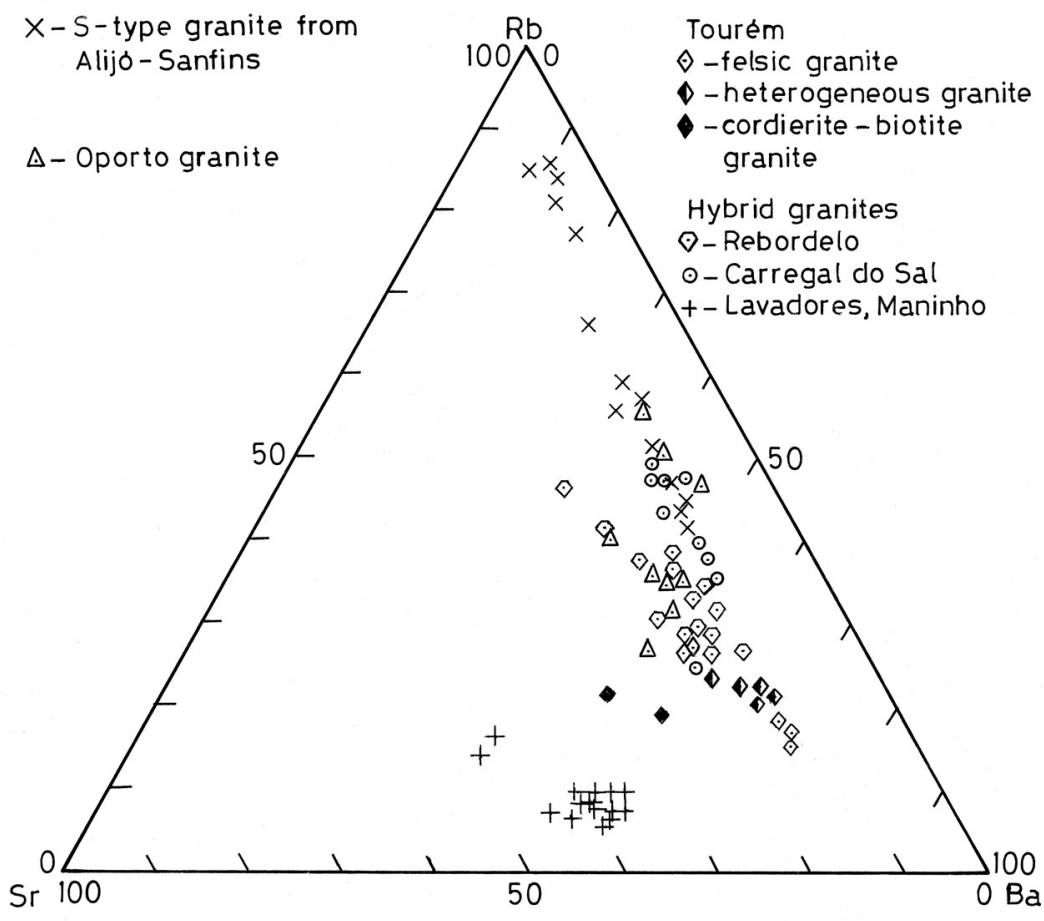

Fig. 3. $R b-B a-S r$ diagram of tin-bearing granites from northern and central Portugal. 
Table 1. Average chemical analyses, trace and rare earth elements of selected tin-bearing S-type granites and Itype granites from northern Portugal associated with tin-tungsten mineralizations.

\begin{tabular}{|c|c|c|c|c|c|c|c|}
\hline & 1 & 2 & 3 & 4 & 5 & 6 & 7 \\
\hline $\mathrm{SiO}_{2}, \mathrm{wt} \%$ & 71.88 & 71.98 & 72.25 & 73.28 & 73.44 & 74.06 & 73.76 \\
\hline $\mathrm{TiO}_{2}$ & 0.26 & 0.22 & 0.11 & 0.07 & 0.16 & 0.10 & 0.20 \\
\hline $\mathrm{Al}_{2} \mathrm{O}_{3}$ & 15.33 & 15.58 & 15.61 & 15.27 & 14.44 & 14.59 & 13.66 \\
\hline $\mathrm{Fe}_{2} \mathrm{O}_{3}$ & 0.23 & 0.36 & 0.42 & 0.21 & 0.40 & 0.36 & 0.37 \\
\hline $\mathrm{FeO}$ & 1.19 & 0.99 & 0.68 & 0.58 & 0.73 & 0.63 & 1.26 \\
\hline $\mathrm{MnO}$ & 0.02 & 0.02 & 0.02 & 0.03 & 0.05 & 0.10 & 0.03 \\
\hline $\mathrm{MgO}$ & 0.13 & 0.14 & 0.05 & 0.04 & 0.04 & 0.18 & 0.51 \\
\hline $\mathrm{CaO}$ & 0.84 & 0.72 & 0.66 & 0.56 & 0.48 & 0.40 & 1.35 \\
\hline $\mathrm{Na}_{2} \mathrm{O}$ & 3.84 & 3.89 & 3.64 & 3.84 & 3.81 & 3.84 & 3.41 \\
\hline $\mathrm{K}_{2} \mathrm{O}$ & 5.13 & 4.62 & 4.84 & 4.61 & 4.78 & 4.36 & 4.66 \\
\hline $\mathrm{P}_{2} \mathrm{O}_{5}$ & 0.29 & 0.28 & 0.32 & 0.30 & 0.30 & 0.34 & 0.08 \\
\hline $\mathrm{H}_{2} \mathrm{O}^{+}$ & 0.82 & 0.98 & 0.99 & 1.04 & 1.18 & 0.90 & 0.63 \\
\hline $\mathrm{H}_{2} \mathrm{O}^{-}$ & 0.21 & 0.14 & 0.52 & 0.34 & 0.16 & 0.19 & 0.10 \\
\hline Total & 100.17 & 99.92 & 100.11 & 100.17 & 99.97 & 100.05 & 100.02 \\
\hline F ppm & n.d. & n.d. & n.d. & n.d. & n.d. & 1930 & 553 \\
\hline $\mathrm{Cr}$ & 10 & 7 & 6 & 4 & 4 & 13 & 23 \\
\hline $\mathrm{V}$ & 17 & 14 & 9 & 6 & 5 & 3 & 12 \\
\hline $\mathrm{Nb}$ & n.d & n.d. & n.d. & n.d. & n.d. & 32 & 21 \\
\hline $\mathrm{Zn}$ & n.d & n.d. & n.d. & n.d. & n.d. & 103 & 88 \\
\hline $\mathrm{Sn}$ & 20 & 32 & 36 & 41 & 48 & 72 & 12 \\
\hline $\mathrm{Li}$ & 355 & 408 & 418 & 445 & 525 & 190 & 112 \\
\hline $\mathrm{Ni}$ & 9 & 7 & 3 & 2 & 3 & 8 & 17 \\
\hline Co & $*$ & * & * & * & $*$ & $*$ & $*$ \\
\hline $\mathrm{Sc}$ & * & * & $*$ & $*$ & $*$ & * & 7 \\
\hline $\mathrm{Zr}$ & 72 & 65 & 62 & 42 & 40 & 61 & 144 \\
\hline Y & 9 & 13 & 9 & 17 & 6 & 46 & 39 \\
\hline $\mathrm{Sr}$ & 82 & 66 & 48 & 33 & 20 & 32 & 97 \\
\hline $\mathrm{Ba}$ & 420 & 306 & 153 & 147 & 35 & 66 & 483 \\
\hline $\mathrm{Rb}$ & 400 & 447 & 563 & 627 & 733 & 500 & 278 \\
\hline $\mathrm{Cs}$ & 25 & 29 & 73 & 110 & 157 & 51 & 7 \\
\hline $\mathrm{La}$ & 20.47 & 19.21 & 10.98 & 9.57 & 5.23 & 10.97 & 33.53 \\
\hline $\mathrm{Ce}$ & 52.70 & 47.45 & 23.74 & 21.84 & 12.52 & 26.31 & 77.00 \\
\hline $\mathrm{Nd}$ & 20.41 & 18.95 & 12.95 & 10.88 & 7.04 & 15.90 & 40.70 \\
\hline $\mathrm{Sm}$ & 3.50 & 3.34 & 2.51 & 2.03 & 1.85 & 2.39 & 9.47 \\
\hline $\mathrm{Eu}$ & 0.56 & 0.53 & 0.40 & 0.29 & 0.14 & 0.23 & 0.58 \\
\hline $\mathrm{Gd}$ & 4.68 & 4.44 & 4.16 & 2.90 & 2.57 & 2.50 & 8.55 \\
\hline $\mathrm{Tb}$ & 0.52 & 0.48 & 0.43 & 0.40 & 0.31 & 0.30 & 1.54 \\
\hline $\mathrm{Yb}$ & 0.77 & 0.57 & 0.54 & 0.44 & 0.40 & 0.34 & 6.82 \\
\hline $\mathrm{Lu}$ & 0.070 & 0.060 & 0.058 & 0.050 & 0.044 & 0.060 & 1.02 \\
\hline
\end{tabular}

1-6- S-type granites; 7-I- type granite. 1, 2, 3, 4 and 5 from Alijó-Sanfins; 6 from Ervedosa; 7 from Carris (Gerez). 1coarse-grained gneissose porphyritic muscovite-biotite granite; 2 - fine-grained gneissose porphyritic muscovite-biotite granite; 3- medium-grained muscovite-biotite granite; 4- fine-grained feebly porphyritic muscovite-biotite granite; 5medium-grained muscovite granite; 6- fine-to medium-grained muscovite granite; 7- fine-grained biotite granite. n.d.not determined; *-below the limit of sensitivity. Analyses by A. Neiva, except analysis 6 by M.E.P. Gomes.

These granites were generated mainly by partial melting of heterogeneous metasedimentary rocks. The isotopic data support a crustal origin (e.g., Chappell \& White 1992). In general, each granite underwent in situ fractional crystallization (e.g., Neiva 1993). Many tin-bearing granites show characteristics of S-type granites (e.g., Ishihara et al. 1980, Neiva 1984, Eugster 1985, Schwartz \& Askury 1989, Haapala 1997). 

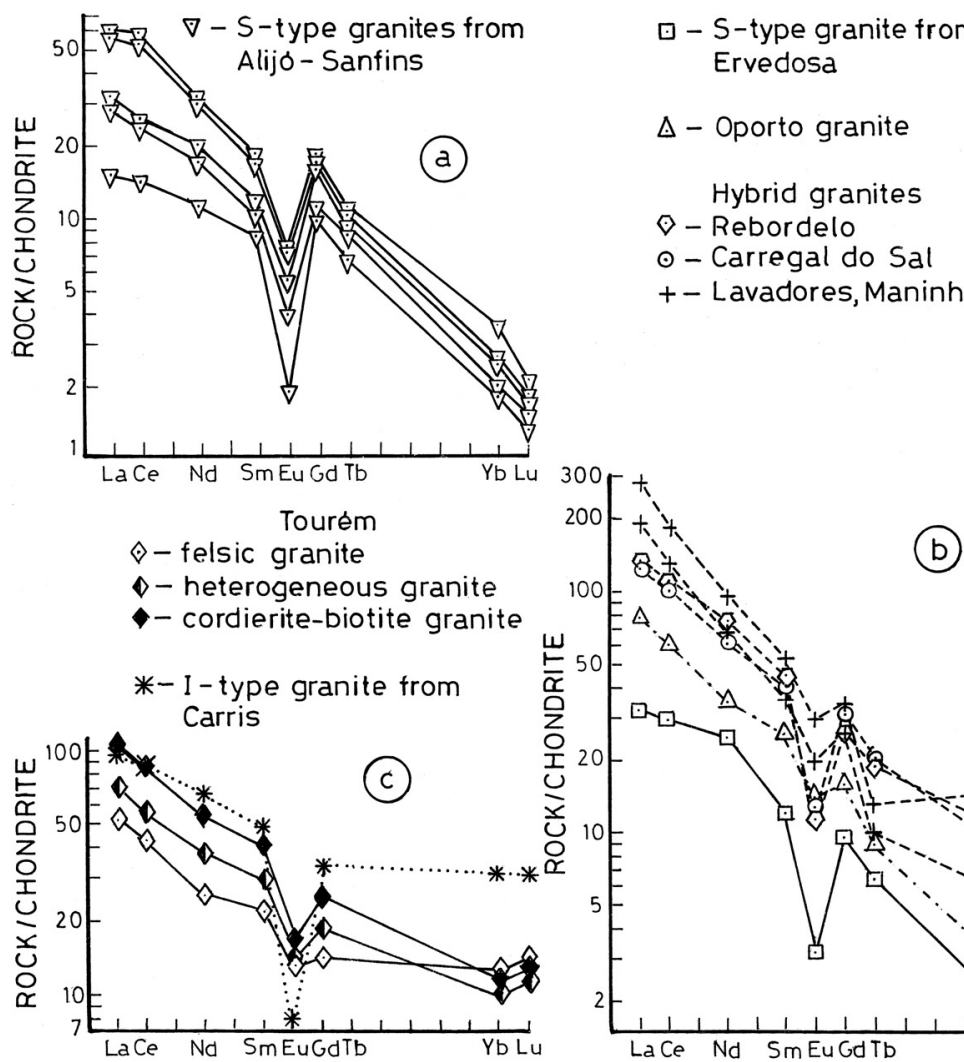
$\square-$ S-type granite from
Ervedosa

$\Delta$ - Oporto granite

Hybrid granites

$\diamond$ - Rebordelo

$\odot$ - Carregal do Sal

+- Lavadores, Maninho $\diamond-$ felsic granite

$\checkmark$ - heterogeneous granite

- cordierite-biotite granite

*-I - type granite from

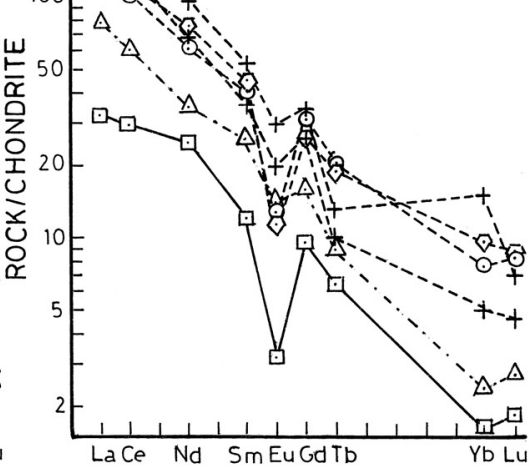

Fig. 4. Chondrite-normalized REE patterns of tinbearing granites from northern and central Portugal. a) S-type granites from Alijó-Sanfins. b) $S$ type granite from Ervedo$s a$, granite transitional between $S$ - and I-types from Oporto, hybrid granites from Rebordelo, Carregal do Sal, Lavadores and Maninho. c) Granites from Tourém, I-type granite from Carris.
Commonly in the two-mica granites, muscovite retains a higher percentage of the total granite tin than coexisting biotite (Neiva 1983, 1993, Silva \& Neiva 1990, Gomes 1996, Neves 1997), because muscovite is more abundant than biotite. In biotite-muscovite granites (Silva \& Neiva 2000), biotite retains a higher percentage of the total granite tin, because biotite is the most abundant mica. The Argemela microgranite has the highest $\mathrm{Sn}$ content, which is mainly due to fine-grained cassiterite (Charoy \& Noronha 1996). Tin-tungsten mineralization is associated with some of these granites (Cotelo Neiva 1972, Neiva 1973, 1984, 1987, Roger et al. 1980, Noronha 1982, Silva \& Neiva 1990, Gomes 1996, Ramos 1998, Gomes \& Neiva 2002).

There are other Hercynian tin-bearing granites in northern and central Portugal, which are less evolved than the tin-bearing S-type granites (Table 2, analyses 1-5; Fig. 3). They contain 28-40 ppm average Sn and up to $13 \mathrm{ppm}$ W. Some are biotite granites and others are two-mica granites with either $\mathrm{Fe}^{2+}$-biotite or muscovite dominating. Those containing $\mathrm{Fe}^{2+}$-biotite, and ilmenite as the sole opaque mineral, are peraluminous with $\mathrm{A} /$ CNK generally between 1.10 and 1.36 , but between 1.05 and 1.16 in the biotite-muscovite granite from Rebordelo (Fig. 1). They contain microgranular enclaves, except the muscovite-biotite granite from Oporto (Fig. 1). They are enriched in LREE with respect to HREE $\left(\mathrm{La}_{\mathrm{N}} / \mathrm{Yb}_{\mathrm{N}}=14\right.$ 33 ) and have negative $\mathrm{Eu}$ anomaly with $\mathrm{Eu} / \mathrm{Eu}^{*}$ of 0.32-0.67 (Fig. 4b). Their ages were determined by $\mathrm{Rb}-\mathrm{Sr}$ isochrons. The Rebordelo granite is $357 \pm 9 \mathrm{Ma}$ and has $\left({ }^{87} \mathrm{Sr} /{ }^{86} \mathrm{Sr}\right)_{0}$ of $0.7087 \pm 0.0007$ and $\varepsilon_{\mathrm{Nd}}(\mathrm{T})$ of -5.6 (Gomes 1996). The Oporto granite is $343 \pm 10 \mathrm{Ma}$, presents $\left({ }^{87} \mathrm{Sr} /{ }^{86} \mathrm{Sr}\right)_{0}$ of $0.7065 \pm 0.0003$ and $\varepsilon_{\mathrm{Nd}}(\mathrm{T})$ of -4.5 (Silva 1995, Silva $\&$ Neiva 1997), while the biotite granite from Carregal do Sal (Fig. 1) is $308 \pm 11 \mathrm{Ma}$ and has $\left({ }^{87} \mathrm{Sr} /{ }^{86} \mathrm{Sr}\right)_{0}$ of $0.7068 \pm 0.0015$ and $\varepsilon_{\mathrm{Nd}}(\mathrm{T})$ of -2.9 to -3.4 (Silva \& Neiva 2000, Silva et al. 2000). 
Table 2. Average chemical analyses, trace and rare earth elements of other tin-bearing granites from northern and central Portugal.

\begin{tabular}{|c|c|c|c|c|c|c|c|c|}
\hline & 1 & 2 & 3 & 4 & 5 & 6 & 7 & 8 \\
\hline $\mathrm{SiO}_{2}$ wt $\%$ & 69.18 & 71.11 & 72.65 & 68.24 & 68.62 & 72.82 & 69.28 & 64.32 \\
\hline $\mathrm{TiO}_{2}$ & 0.50 & 0.52 & 0.28 & 0.60 & 0.57 & 0.17 & 0.53 & 0.86 \\
\hline $\mathrm{Al}_{2} \mathrm{O}_{3}$ & 15.44 & 14.23 & 14.85 & 14.74 & 15.52 & 13.82 & 15.16 & 15.90 \\
\hline $\mathrm{Fe}_{2} \mathrm{O}_{3}$ & 0.32 & 0.27 & 0.17 & 0.72 & 0.43 & 1.46 & 3.93 & 6.16 \\
\hline $\mathrm{FeO}$ & 2.45 & 2.51 & 1.30 & 2.32 & 2.18 & n.d & n.d. & n.d. \\
\hline $\mathrm{MnO}$ & 0.11 & 0.06 & 0.09 & 0.13 & 0.12 & 0.01 & 0.04 & 0.05 \\
\hline $\mathrm{MgO}$ & 1.04 & 0.78 & 0.57 & 1.59 & 1.20 & 0.47 & 1.37 & 2.32 \\
\hline $\mathrm{CaO}$ & 1.72 & 1.34 & 0.88 & 2.62 & 2.47 & 0.53 & 1.02 & 1.67 \\
\hline $\mathrm{Na}_{2} \mathrm{O}$ & 3.41 & 2.82 & 3.35 & 3.25 & 3.82 & 2.78 & 2.49 & 3.31 \\
\hline $\mathrm{K}_{2} \mathrm{O}$ & 4.76 & 5.22 & 4.63 & 4.29 & 4.08 & 5.91 & 4.08 & 3.26 \\
\hline $\mathrm{P}_{2} \mathrm{O}_{5}$ & 0.22 & 0.25 & 0.33 & 0.37 & 0.24 & 0.23 & 0.32 & 0.25 \\
\hline $\mathrm{H}_{2} \mathrm{O}+$ & 0.55 & 0.21 & 0.71 & 0.73 & 0.60 & & & \\
\hline $\mathrm{H}_{2} \mathrm{O}_{-}$ & 0.14 & 0.56 & 0.12 & 0.09 & 0.07 & 0.97 & 1.33 & 1.23 \\
\hline Total & 99.90 & 99.88 & 99.93 & 99.69 & 99.92 & 99.17 & 99.67 & 99.33 \\
\hline $\mathrm{F} \quad \mathrm{ppm}$ & 1279 & 2100 & 1332 & 1874 & 1194 & n.d. & 576 & 593 \\
\hline $\mathrm{Cr}$ & 35 & 13 & 12 & 27 & 20 & 17 & 47 & 81 \\
\hline V & 44 & 35 & 16 & 65 & 57 & 7 & 49 & 63 \\
\hline $\mathrm{Nb}$ & 18 & 23 & 9 & 46 & 28 & n.d. & 15 & 27 \\
\hline $\mathrm{Zn}$ & 61 & 61 & 73 & 48 & 38 & 27 & 82 & 114 \\
\hline Sn & 36 & 32 & 28 & 28 & 40 & n.d. & 26 & 53 \\
\hline $\mathrm{Li}$ & 143 & 96 & 92 & 40 & 44 & n.d. & 47 & 47 \\
\hline $\mathrm{Ni}$ & 8 & 18 & 30 & 18 & 19 & 9 & 27 & 31 \\
\hline $\mathrm{Zr}$ & 217 & 253 & 131 & 352 & 297 & 87 & 153 & 192 \\
\hline $\mathrm{Sc}$ & 7 & 8 & * & 9 & 8 & 4 & 9 & 16 \\
\hline Y & 54 & 38 & 16 & 28 & 20 & 29 & 26 & 30 \\
\hline $\mathrm{Sr}$ & 150 & 95 & 116 & 935 & 702 & 163 & 138 & 175 \\
\hline $\mathrm{Ba}$ & 465 & 402 & 320 & 1160 & 1022 & 919 & 557 & 373 \\
\hline $\mathrm{Rb}$ & 282 & 315 & 252 & 178 & 139 & 160 & 157 & 165 \\
\hline Cs & 24 & 14 & 10 & 11 & 6 & n.d. & $*$ & $*$ \\
\hline $\mathrm{La}$ & 45.50 & 44.80 & 26.80 & 96.6 & 65.2 & 17.55 & 24.20 & 35.60 \\
\hline $\mathrm{Ce}$ & 100.4 & 94.6 & 55.10 & 165.7 & 115.8 & 39.13 & 51.40 & 76.94 \\
\hline $\mathrm{Nd}$ & 48.2 & 40.0 & 22.5 & 60.1 & 42.7 & 16.88 & 23.53 & 35.04 \\
\hline $\mathrm{Sm}$ & 9.00 & 8.20 & 5.01 & 10.28 & 7.20 & 4.33 & 5.62 & 7.75 \\
\hline $\mathrm{Eu}$ & 0.85 & 0.94 & 1.03 & 2.21 & 1.45 & 0.98 & 1.03 & 1.24 \\
\hline $\mathrm{Gd}$ & 6.76 & 8.03 & 4.23 & 8.80 & 6.85 & 3.72 & 4.64 & 6.54 \\
\hline $\mathrm{Tb}$ & 0.90 & 0.94 & 0.43 & 0.61 & 0.49 & n.d. & n.d. & n.d. \\
\hline $\mathrm{Yb}$ & 2.15 & 1.69 & 0.52 & 3.34 & 1.10 & 2.76 & 2.25 & 2.58 \\
\hline $\mathrm{Lu}$ & 0.27 & 0.29 & 0.09 & 0.24 & 0.16 & 0.47 & 0.36 & 0.45 \\
\hline
\end{tabular}

1- Rebordelo; 2- Carregal do Sal; 3- Oporto; 4- Lavadores; 5- Maninho; 6, 7 and 8- Tourém. 1-medium-grained porphyritic biotite-muscovite granite; 2 - coarse- to very coarse-grained porphyritic biotite granite; 3 - medium-grained muscovitebiotite granite; 4- medium- to coarse-grained porphyritic biotite granite; 5- medium- to fine-grained porphyritic biotite granite; 6- fine- to coarse-grained felsic granite; 7- coarse-grained heterogeneous granite; 8- coarse- to medium grained cordierite-biotite granite: n.d. - not determined, * - below the limit of sensitivity. $\mathrm{Fe}_{2} \mathrm{O}_{3}$ values for analyses 6,7 and 8 correspond to total $\mathrm{Fe}_{2} \mathrm{O}_{3}$; for these analyses $\mathrm{H}_{2} \mathrm{O}^{+}$and $\mathrm{H}_{2} \mathrm{O}$ are given together. Analyses: 1 by Gomes (1996); $2-5$ by Silva (1995); 6-8 by Holtz and Barbey (1991) with F, Nb, Sn, Li and Cs by Neiva (1994).

These granites have petrographic and geochemical characteristics typical for S-type granite (see Chappell \& White 1992). However, the Rebordelo granite and Carregal do Sal granite have high- er La and Ce contents and $\varepsilon_{\mathrm{Nd}}(\mathrm{T})$; the former also contains higher $\mathrm{Y}$ and the latter has lower initial ${ }^{87} \mathrm{Sr} /{ }^{86} \mathrm{Sr}$ ratio than S-type granites. The Oporto granite shows lower initial ${ }^{87} \mathrm{Sr} /{ }^{86} \mathrm{Sr}$ ratio and high- 
Table 3. Representative chemical analyses, trace and rare earth elements of unaltered granites and greisenized granites from S. Mamede de Ribatua and Panasqueira and of their muscovites.

\begin{tabular}{|c|c|c|c|c|c|c|c|c|c|}
\hline & & Gra & & & & & Musc & & \\
\hline & $1 \mathrm{a}$ & $1 \mathrm{~b}$ & $2 \mathrm{a}$ & $2 b$ & & $1 \mathrm{a}$ & $1 \mathrm{~b}$ & $2 \mathrm{a}$ & $2 \mathrm{~b}$ \\
\hline $\mathrm{SiO}_{2}$ wt $\%$ & 72.33 & 75.96 & 73.41 & 74.11 & $\mathrm{SiO}_{2}$ & 45.74 & 46.13 & 46.16 & 45.63 \\
\hline $\mathrm{TiO}_{2}$ & 0.23 & - & 0.20 & 0.01 & $\mathrm{TiO}_{2}$ & 0.60 & 0.54 & 0.50 & -- \\
\hline $\mathrm{Al}_{2} \mathrm{O}_{3}$ & 15.22 & 11.32 & 14.40 & 14.95 & $\mathrm{Al}_{2} \mathrm{O}_{3}$ & 32.97 & 32.16 & 31.87 & 32.99 \\
\hline $\mathrm{Fe}_{2} \mathrm{O}_{3}$ & 0.34 & 0.37 & 0.28 & 0.56 & $\mathrm{Fe}_{2} \mathrm{O}_{3}$ & 0.91 & 1.03 & 1.22 & 1.13 \\
\hline $\mathrm{FeO}$ & 1.08 & 0.75 & 1.33 & 1.54 & $\mathrm{FeO}$ & 2.34 & 1.37 & 3.03 & 3.27 \\
\hline $\mathrm{MnO}$ & 0.02 & - & 0.05 & 0.03 & $\mathrm{MnO}$ & 0.06 & 0.18 & 0.05 & 0.06 \\
\hline $\mathrm{MgO}$ & 0.12 & - & 0.44 & 0.09 & $\mathrm{MgO}$ & 2.17 & 2.74 & 1.30 & -- \\
\hline $\mathrm{CaO}$ & 0.65 & 0.65 & 0.49 & 0.30 & $\mathrm{CaO}$ & -- & 0.25 & -- & -- \\
\hline $\mathrm{Na}_{2} \mathrm{O}$ & 3.73 & 2.55 & 3.02 & 1.50 & $\mathrm{Na}_{2} \mathrm{O}$ & 0.41 & 0.28 & 0.47 & 0.47 \\
\hline $\mathrm{K}_{2} \mathrm{O}$ & 4.94 & 6.05 & 4.58 & 4.05 & $\mathrm{~K}_{2} \mathrm{O}$ & 10.86 & 10.36 & 11.41 & 11.55 \\
\hline $\mathrm{P}_{2} \mathrm{O}_{5}$ & 0.35 & 0.47 & 0.37 & 0.22 & $\mathrm{Cl}$ & 0.02 & 0.07 & -- & -- \\
\hline $\mathrm{B}_{2} \mathrm{O}_{3}$ & 0.06 & 0.08 & n.d. & n.d. & $\mathrm{F}$ & 0.03 & 0.55 & 1.52 & 1.16 \\
\hline $\mathrm{H}_{2} \mathrm{O}^{+}$ & 0.91 & 2.00 & 1.30 & 2.28 & $\mathrm{H}_{2} \mathrm{O}^{+}$ & 4.04 & 4.05 & 3.15 & 3.95 \\
\hline $\mathrm{H}_{2} \mathrm{O}^{-}$ & 0.16 & 0.23 & 0.15 & 0.27 & & 100.15 & 99.71 & 100.68 & 100.21 \\
\hline Total & 100.04 & 100.43 & 100.02 & 99.91 & $0 \equiv \mathrm{Cl}$ & -- & 0.02 & -- & -- \\
\hline & & & & & $0 \equiv \mathrm{F}$ & 0.01 & 0.23 & 0.64 & 0.49 \\
\hline & & & & & Total & 100.14 & 99.46 & 100.04 & 99.72 \\
\hline Sn ppm & 18 & 1250 & 15 & 92 & $\mathrm{Sn}$ & 144 & 300 & 155 & 230 \\
\hline $\mathrm{W}$ & 2 & 6 & 3 & 22 & W & 4 & 24 & 46 & 50 \\
\hline $\mathrm{Nb}$ & 25 & 35 & 23 & 43 & $\mathrm{Nb}$ & 23 & 29 & 108 & 121 \\
\hline $\mathrm{Ta}$ & 6 & 8 & 4 & 15 & $\mathrm{Ta}$ & n.d. & n.d. & 8 & 35 \\
\hline $\mathrm{Zn}$ & 40 & 55 & 68 & 467 & $\mathrm{Zn}$ & 30 & 116 & 283 & 359 \\
\hline $\mathrm{Li}$ & 195 & 100 & 237 & 313 & $\mathrm{Li}$ & 1460 & 800 & 996 & 847 \\
\hline $\mathrm{Rb}$ & 486 & 700 & 617 & 816 & $\mathrm{Rb}$ & 1780 & 500 & 2278 & 2260 \\
\hline $\mathrm{Cs}$ & 35 & 29 & 7 & 19 & $\mathrm{Cs}$ & 137 & 100 & 36 & 70 \\
\hline $\mathrm{Cr}$ & 11 & 11 & 23 & 20 & $\mathrm{Cr}$ & 13 & 8 & 22 & 19 \\
\hline V & 11 & $*$ & 16 & 5 & $\mathrm{~V}$ & 34 & 13 & 22 & 7 \\
\hline $\mathrm{Ni}$ & 9 & 7 & n.d. & n.d. & $\mathrm{Ni}$ & 5 & $*$ & 25 & 20 \\
\hline $\mathrm{Cu}$ & n.d. & n.d. & 9 & 111 & $\mathrm{Cu}$ & 11 & 16 & $*$ & $*$ \\
\hline $\mathrm{Ba}$ & 174 & 170 & 80 & 34 & $\mathrm{Ba}$ & 79 & 40 & 35 & 85 \\
\hline $\mathrm{Pb}$ & 28 & 100 & 21 & 100 & & & & & \\
\hline $\mathrm{Sc}$ & 10 & 5 & 5 & * & & & & & \\
\hline $\mathrm{Zr}$ & 108 & 92 & 85 & 27 & & & & & \\
\hline $\mathrm{Sr}$ & 38 & 31 & 26 & 18 & & & & & \\
\hline $\mathrm{F}$ & n.d. & n.d. & 3421 & 3405 & & & & & \\
\hline S & n.d. & n.d. & 300 & 1000 & & & & & \\
\hline $\mathrm{Be}$ & 25 & 15 & n.d. & n.d. & & & & & \\
\hline $\mathrm{Ga}$ & 28 & 92 & n.d. & n.d. & & & & & \\
\hline $\mathrm{La}$ & 29.28 & 19.04 & & & & & & & \\
\hline $\mathrm{Ce}$ & 70.42 & 45.50 & & & & & & & \\
\hline $\mathrm{Nd}$ & 31.75 & 24.32 & & & & & & & \\
\hline $\mathrm{Sm}$ & 6.01 & 3.90 & & & & & & & \\
\hline $\mathrm{Eu}$ & 0.45 & 0.37 & & & & & & & \\
\hline $\mathrm{Gd}$ & 4.34 & 3.12 & & & & & & & \\
\hline $\mathrm{Tb}$ & 0.48 & 0.47 & & & & & & & \\
\hline $\mathrm{Yb}$ & 0.44 & 1.50 & & & & & & & \\
\hline $\mathrm{Lu}$ & 0.034 & 0.20 & & & & & & & \\
\hline
\end{tabular}

1a and $1 \mathrm{~b}-\mathrm{S}$. Mamede de Ribatua; 2a, 2 b - Panasqueira. 1a- unaltered fine- to medium-grained porphyritic muscovitebiotite granite, $1 \mathrm{~b}$ - greisenized granite; $2 \mathrm{a}$ - fine- to medium-grained porphyritic two-mica granite, $2 \mathrm{~b}$ - greisenized granite. - not detected, n.d. - not determined, * - below the limit of sensitivity. Analyses by A. Neiva. 
er $\varepsilon_{\mathrm{Nd}}(\mathrm{T})$ than $\mathrm{S}$-type granites. Therefore, their isotopic characteristics correspond generally to I-type granites (derived by partial melting of igneous rocks). Many Australian tin-bearing granites have mixed characteristics of I- and S-types of granite (Solomon et al. 1994). In the biotite-muscovite granite, biotite retains a higher percentage of total granite tin than coexisting muscovite, because biotite is more abundant than muscovite. In this granite, the partition ratio for $\mathrm{Sn}$ between biotite and coexisting muscovite is $<1$. In the muscovitebiotite granite, muscovite retains the highest percentage of total granite tin, because muscovite is more abundant than biotite and Sn favors muscovite rather than biotite.

Generally tin-tungsten deposits were not found in association with these granites. However quartz veins with scheelite $>$ cassiterite are associated with the peraluminous biotite-muscovite granite from Rebordelo, which has the highest $\left({ }^{87} \mathrm{Sr} /{ }^{86} \mathrm{Sr}\right)_{0}$ of $0.7087 \pm 0.0007$ and the lowest $\varepsilon_{\mathrm{Nd}}(\mathrm{T})$ of -5.6 . This granite was derived from a tonalite magma by fractional crystallization and assimilation of metasediments (Gomes 1996).

The peraluminous muscovite-biotite granite from Oporto was probably derived from partial fusion of orthogneiss (Silva 1995). The peraluminous biotite granite from Carregal do Sal was derived by mixing of a granite magma (formed by partial melting of a pelitic metasedimentary source) with a basic magma (Silva \& Neiva 2000).

\section{Biotite granites}

The biotite granites containing Mg-biotite, allanite and magnetite are metaluminous to peraluminous $(\mathrm{A} / \mathrm{CNK}=0.98-1.10)$ with high $\mathrm{K}_{2} \mathrm{O}$ up to 4.68 wt. $\%$ and Sn content of $28-40$ ppm. They are the richest in $\mathrm{Sr}$ and the poorest in $\mathrm{Rb}$ (Fig. 3). The granite at Lavadores (Fig. 1) also contains titanite and rare hornblende; it is calc-alkaline to sub-alkaline, has an age of $314 \pm 11 \mathrm{Ma}$, and shows initial ratios $\left({ }^{87} \mathrm{Sr} /{ }^{86} \mathrm{Sr}\right)_{0}$ of $0.7044 \pm 0.0000$ (determined by whole-rock $\mathrm{Rb}-\mathrm{Sr}$ isochron) and $\varepsilon_{\mathrm{Nd}}(\mathrm{T})$ of -0.8 . The biotite granite from Maninho (Fig. 1) also contains ilmenite, is calc-alkaline and for the age of $280 \mathrm{Ma}$ has initial $\left({ }^{87} \mathrm{Sr} /{ }^{86} \mathrm{Sr}\right)$ ratio ranging between 0.7048 and 0.7052 (Silva 1995, Silva \& Neiva 1997). Commonly they contain microgranular enclaves. They have mineralogical, chemical and isotopic features of I-type granite, but they present higher Sr and La contents; Lavadores granite also has higher $\mathrm{Nb}$ and $\mathrm{Zr}$ contents than I-type granite (see Chappell \& White 1992). The biotite granites from Lavadores and Maninho are interpreted as hybrid (Silva 1995, Silva \& Neiva 1997), but the initial $\mathrm{Sr}$ and $\mathrm{Nd}$ isotope values suggest mainly a mantle origin. They are enriched in LREE with respect to HREE $\left(\mathrm{La}_{\mathrm{N}} / \mathrm{Yb}_{\mathrm{N}}\right.$ = 19-38), have a smaller negative Eu anomaly $\left(\mathrm{Eu} / \mathrm{Eu}^{*}=0.63-0.73\right)$ and are richer in LREE and $\sum$ REE than Portuguese tin-bearing granites of Stype (Figs. 4a, b). Tin-tungsten deposits are not known to be associated with these granites.

The felsic granite, heterogeneous granite and cordierite-biotite granite from Tourém (Fig. 1 and Table 2, analyses 6, 7 and 8) are peraluminous with A/CNK of 1.11-1.92 and have 26-53 ppm Sn with the highest value in the cordierite-biotite granite (Neiva 1994), but ore deposits are not known in this area. The amount of biotite increases from $<5 \%$ in felsic granite up to $25 \%$ in cordierite-biotite granite. Biotite retains up to $76 \%$ of total granite tin, while muscovite retains only up to $3 \%$. These granites have an emplacement age of $303 \pm 5 \mathrm{Ma}$ given by the U/Pb age of monazite (Holtz \& Juteau 1987), Eu/Eu* of 0.52-0.73, and show the lowest enrichment in LREE with respect to HREE with $\mathrm{La}_{\mathrm{N}} / \mathrm{Yb}_{\mathrm{N}}$ between 4 and 9. The $\sum R E E, L R E E, \mathrm{La}_{\mathrm{N}} / \mathrm{Yb}_{\mathrm{N}}$ and negative Eu anomaly increase from felsic granite to cordierite-biotite granite (Fig. 4c). They may have been formed by sequential higher degrees of partial melting of orthogneiss with progressive less efficient segregation of restitic materials (Holtz \& Barbey 1991).

These granites have mineralogical and most chemical characteristics similar to those of S-type granites from LFB (Chappell \& White 1992). However, the felsic granite has higher $\mathrm{K}_{2} \mathrm{O}$ and $\mathrm{Ba}$ contents, the cordierite-biotite granite shows higher $\mathrm{Zn}$ content, and the latter granite and the heterogeneous granite present higher $\mathrm{Al}_{2} \mathrm{O}_{3}$ values for their $\mathrm{SiO}_{2}$ contents than $\mathrm{S}$-type granites. 
The A-type granites are characterized by higher contents of $\mathrm{Y}, \mathrm{REE}, \mathrm{Ga}, \mathrm{Zr}$, and $\mathrm{Nb}$ than the Iand S-type granites (Chappell \& White 1992). The Portuguese unaltered tin-bearing granites (Tables 1, 2 and 3) have lower contents of these elements than A-type granite of similar $\mathrm{SiO}_{2}$ content (Collins et al. 1982, Whalen et al. 1987). Furthermore, biotite of the Portuguese granites has not as high $\mathrm{Fe} / \mathrm{Mg}$ as biotite of the A-type granites (Whalen et al. 1987).

\section{PORTUGUESE TIN-BEARING GRANITIC SUITES}

Three fractionation suites of tin-bearing S-type granites were distinguished. At Alijó-Sanfins (Fig. $1)$, the suite consists of four muscovite-biotite granites and a muscovite granite (Table 1, analyses 1-5). At Ervedosa (Fig. 1), two muscovite-biotite granites and a muscovite granite define another suite (Gomes \& Neiva 2002). Data on this muscovite granite is given in Table 1 (analysis 6). These granites contain quartz, K-feldspar, plagioclase, \pm biotite, tourmaline, monazite, apatite, zircon, ilmenite and rutile. They are strongly differentiated peraluminous granites (Fig. 5a) with A/ CNK of 1.14-1.26 at Alijó-Sanfins and of 1.101.41 at Ervedosa. The most evolved tin-bearing granites from both suites have the highest Sn contents and plot in field III of Fig. 5c, while the other granites of these suites fall in field II. Each suite defines a linear correlation in the $\log \mathrm{Sn}-\log \mathrm{Rb} /$ $\mathrm{Sr}$ and $\log \mathrm{Sn}-\log \mathrm{Rb} / \mathrm{Ba}$ plots (Figs. 6a, b), which indicates fractional crystallization (Rayleigh fractionation).

In both suites, primary muscovite retains a higher percentage of total granite Sn than coexisting biotite. With increasing fractional crystallization, the amount of muscovite increases and the amount of biotite decreases in both suites. Therefore, the percentage of total granite tin retained in muscovite increases and reaches $72 \%$ and $81 \%$ in muscovite granites from Alijó-Sanfins and Ervedosa, respectively.

The chondrite normalized REE patterns for the suite from Alijó-Sanfins are subparallel. There is a decrease in $\sum$ REE and increase in the negative $\mathrm{Eu}$ anomaly with increase in the degree of fractionation (Fig. 4a).

The early aplite dykes and microgranite from Argemela (Fig. 1) (Charoy \& Noronha 1996) also define together a linear correlation in each diagram (Figs. 6a, b) and therefore they define the third suite. The early aplite dykes contain quartz, albite, unzoned muscovite, rare biotite, amblygonite, cassiterite, rutile and zircon. Aplite is peraluminous with $\mathrm{A} / \mathrm{CNK}$ of $1.11-1.20$ and has $\mathrm{Na}_{2} \mathrm{O}$ up to $9.30 \mathrm{wt} . \%$. The microgranite consists of quartz, albite, muscovite (partially replaced by lepidolite), a phosphate of the amblygonite series, cassiterite, beryl, and columbite-tantalite. It is strongly peraluminous with A/CNK of 1.34-2.01, but with ASI $[\mathrm{Al} /(\mathrm{Na}+\mathrm{K}+\mathrm{Ca}+\mathrm{Li}+\mathrm{P})$ in mole \%] of $1.02-1.15$. The ASI values are preferred, because the microgranite contains amblygonite, which is mainly responsible for the high contents of $\mathrm{Li}$ and $\mathrm{P}$ of the rock. The microgranite is highly sodic with $\mathrm{Na}_{2} \mathrm{O}$ up to 5.94 wt.\%, extremely enriched in $\mathrm{F}, \mathrm{P}, \mathrm{Rb}$, $\mathrm{Cs}, \mathrm{Li}, \mathrm{Sn}$ and Be and extremely depleted in $\mathrm{Sr}$, $\mathrm{Ba}, \mathrm{Zr}$ and REE (Charoy \& Noronha 1996). Aplite and microgranite are strongly differentiated (Fig. 5a) and both fall in the field III (Fig. 5c), but the microgranite is richer in $\mathrm{Rb}, \mathrm{Cs}, \mathrm{Sn}$ and poorer in $\mathrm{Ba}$ than aplite. The microgranite probably represents a pegmatitic residual which may have been derived from aplite magma by fractional crystallization (Figs. 6a, b), resulting in an increase of $\mathrm{Sn}$ as a function of the degree of fractionation.

The microgranite from Argemela has the highest Sn content (Figs. 6a, b), because it contains cassiterite. It also has the greatest $\mathrm{Rb} / \mathrm{Sr}$ and $\mathrm{Rb} /$ $\mathrm{Ba}$ ratios. Only at Argemela, $\mathrm{Sn}$ is positively correlated with $\mathrm{Li}$ and $\mathrm{F}$ (Figs. 6c, d). The three suites have different slopes (Figs. 6a, b), which depend on the Sn content of the least evolved granite, its degree of fractionation and the degree of fractionation reached in each suite.

At Alijó-Sanfins, there are W-Sn-bearing quartz veins (Neiva 1996) associated with the tin-bearing granitic suite. At Ervedosa, tin-bearing quartz veins are also related to the tin-bearing granitic suite. 


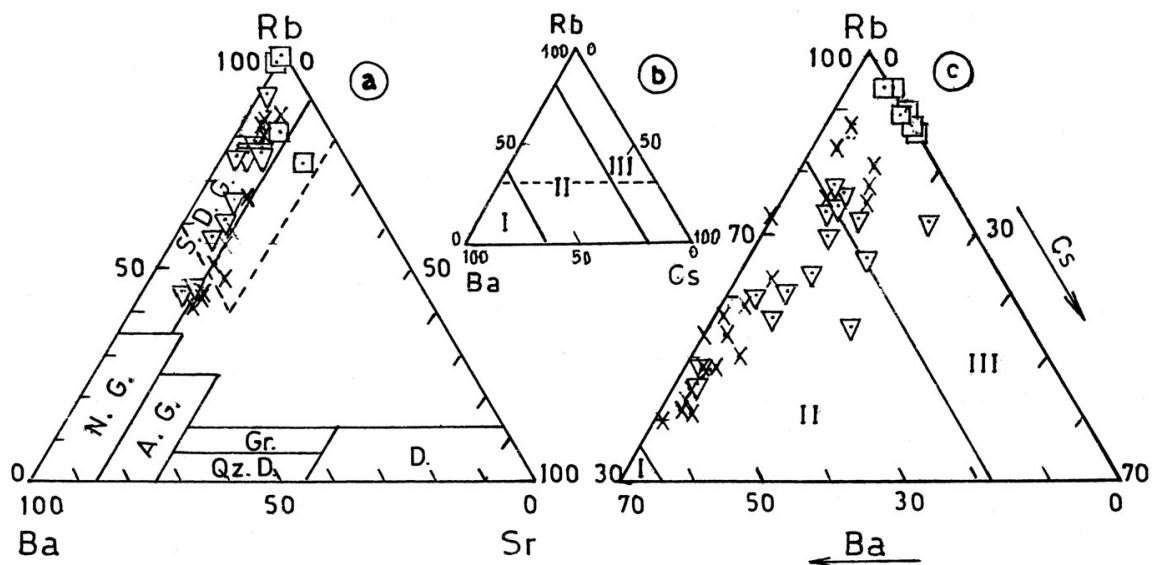

$\nabla$-Alijó-Sanfins, x-Ervedosa, $\square$-Argemela.

Fig. 5. Tin-bearing S-type granitic rocks of the suites from Alijó-Sanfins, Ervedosa and Argemela. a) Rb-Sr-Ba diagram (El Bouseily \& El Sokkary 1975) with the extension of the field S.D.G. by Biste (1979). b) and c) Rb-CsBa diagram (Neiva 1984) with $b$ showing the location of $c$. The fields in Fig. 5a: D - diorites, Qz.D. - quartz diorites, Gr. - granodiorites, A.G. - anomalous granites, N.G. - normal granites, S.D.G. - strongly differentiated granites. The fields in Figs. $5 b$ and c: I - granitic rocks with $S n \leq 15$ ppm, II and III with Sn > 15 ppm, but progressively more evolved.
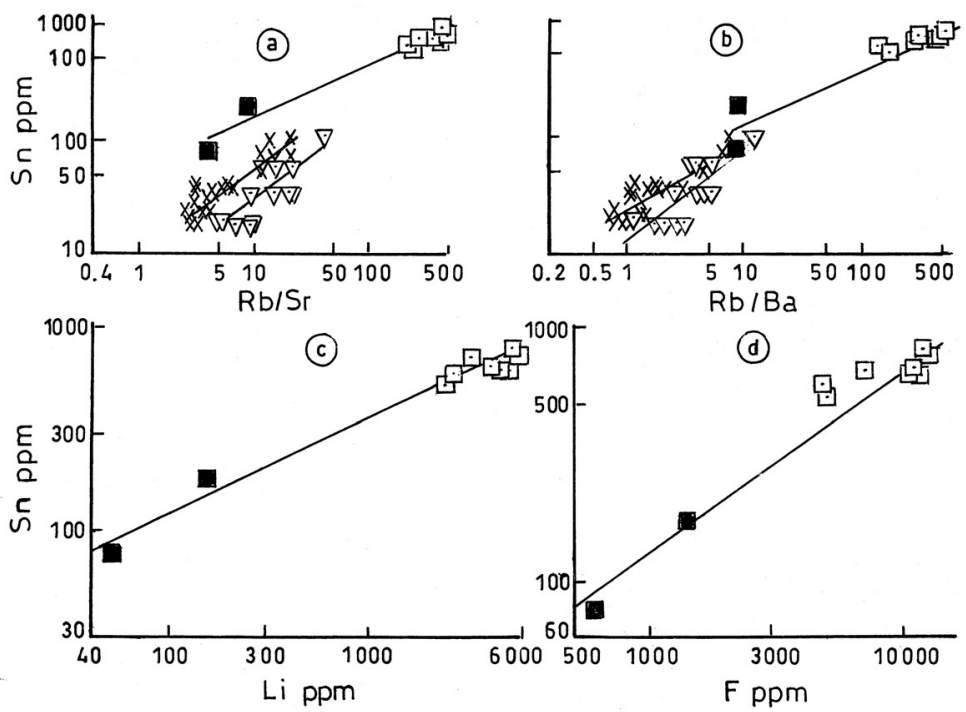

Granites: $\nabla$-Alijó-Sanfins, $x$-Ervedosa

- aplite, $\square$-microgranite from Argemela
Fig. 6. Behaviour of Sn in the tin-bearing granitic suites of Alijó-Sanfins, Ervedosa and Argemela. a) $\mathrm{Sn}-\mathrm{Rb} / \mathrm{Sr}$, b) Sn-Rb/ $B a, c) S n-L i, d) S n-F$ variation diagrams. 
At Argemela, the tin deposit consists of cassiterite-bearing quartz veins which intersect spotted schists. Ribeiro et al. (1974) and Charoy and Noronha (1996) conclude that these tin-bearing veins are not genetically related to the microgranite which contains cassiterite. However, Sn and W mineralizations are commonly related to specialized granites (e.g., Heinrich 1990) and the Argemela microgranite is strongly specialized.

At Argemela, cassiterite from quartz veins has more $\mathrm{Ti}$ and less $\mathrm{Nb}+\mathrm{Ta}$ than cassiterite from microgranite (data of Charoy \& Noronha 1996). Cassiterite from microgranite has the chemical characteristics of cassiterite from pegmatite, differing clearly from hydrothermal cassiterite of quartz veins (Neiva 1996). The hydrothermal fluids responsible for the origin of tin-bearing quartz veins may be derived from the microgranitic volatilerich magma.

\section{MAGMATIC CHARACTERISTICS OF A PORTUGUESE GRANITE ASSOCIATED WITH A TUNGSTEN-ONLY DEPOSIT}

The wolframite-bearing quartz veins from Carris (Fig. 1), northern Portugal, are associated with a fine-grained biotite granite of I-type, which con- tains quartz, K-feldspar, andesine-oligoclase, biotite, titanite, allanite, ilmenite, magnetite, fluorite and sulphides. It is peraluminous with $\mathrm{A} / \mathrm{CNK}$ of 1.02-1.06 and has $12 \pm 8 \mathrm{ppm}$ Sn (Table 1, analysis 7). Therefore it is not a tin-bearing granite. It has a large negative Eu anomaly and is richer in all rare earths, but is less enriched in LREE with respect to HREE $\left(\mathrm{La}_{N} / \mathrm{Yb}_{\mathrm{N}}=3\right)$ than the Portuguese tin-bearing granites of S-type (Figs. 4a, c). It has an age of $302 \pm 4$ Ma with $\left({ }^{87} \mathrm{Sr} /{ }^{86} \mathrm{Sr}\right)_{0}$ of $0.7052 \pm 0.0005$ (Fig. 7), as determined from a whole-rock Rb-Sr isochron (Neiva 1993). Contents of major and trace elements and initial ${ }^{87} \mathrm{Sr} /$ ${ }^{86} \mathrm{Sr}$ ratio are similar to those of I-type granite from LFB (Chappell \& White 1992), but Zn content is slightly higher.

\section{GREISENIZATION}

At S. Mamede de Ribatua (Alijó) and Panasqueira (Fig. 1), tin and tungsten mineralizations are associated with Hercynian S-type two-mica granites, which show local greisenization at the first locality (Neiva 1974) and intensive greisenization in an underground cupola within the batholith at $\mathrm{Pa}$ nasqueira (Neiva 1987). At S. Mamede de Ribatua there are stanniferous aplite-pegmatite veins

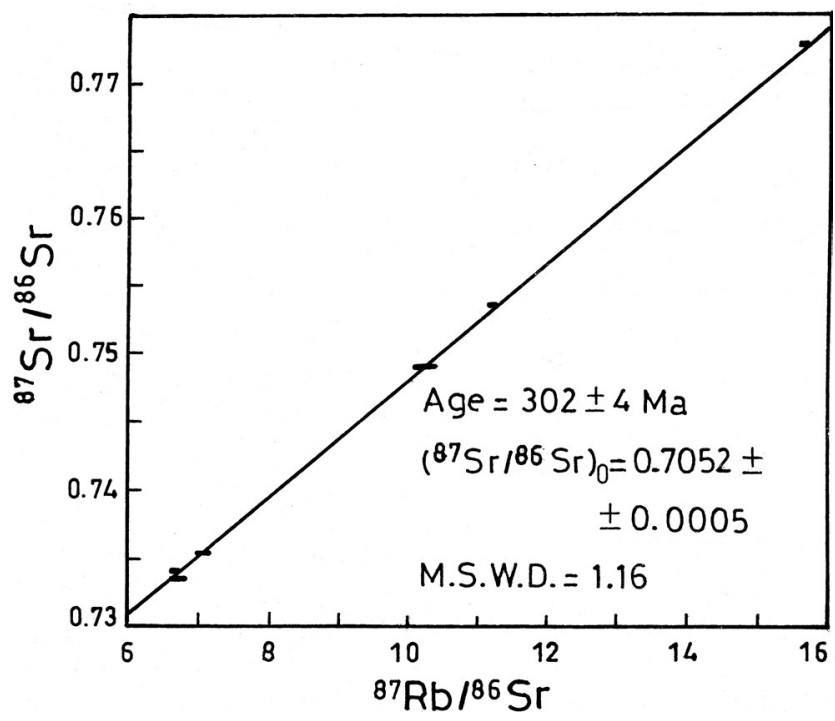

Fig. 7. Whole-rock Rb-Sr isochron of biotite granite from Carris (Gerez). 

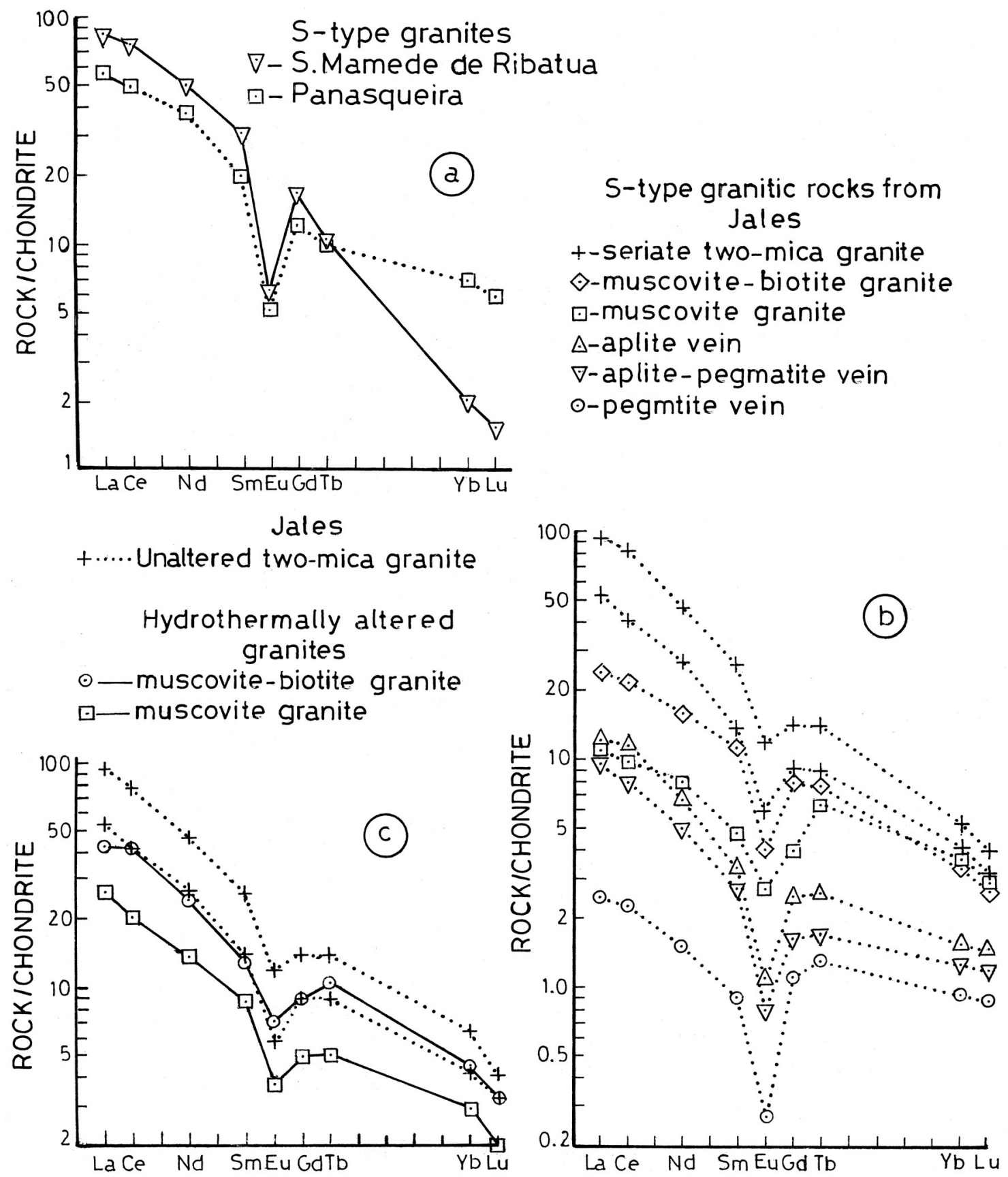

Fig. 8. Chondrite normalized REE abundances of granitic rocks from northern and central Portugal. a) S-type granites from S. Mamede de Ribatua and Panasqueira. b) S-type granitic rocks from Jales. c) behaviour of REE during hydrothermal alteration of the seriate two-mica granite from Jales. 

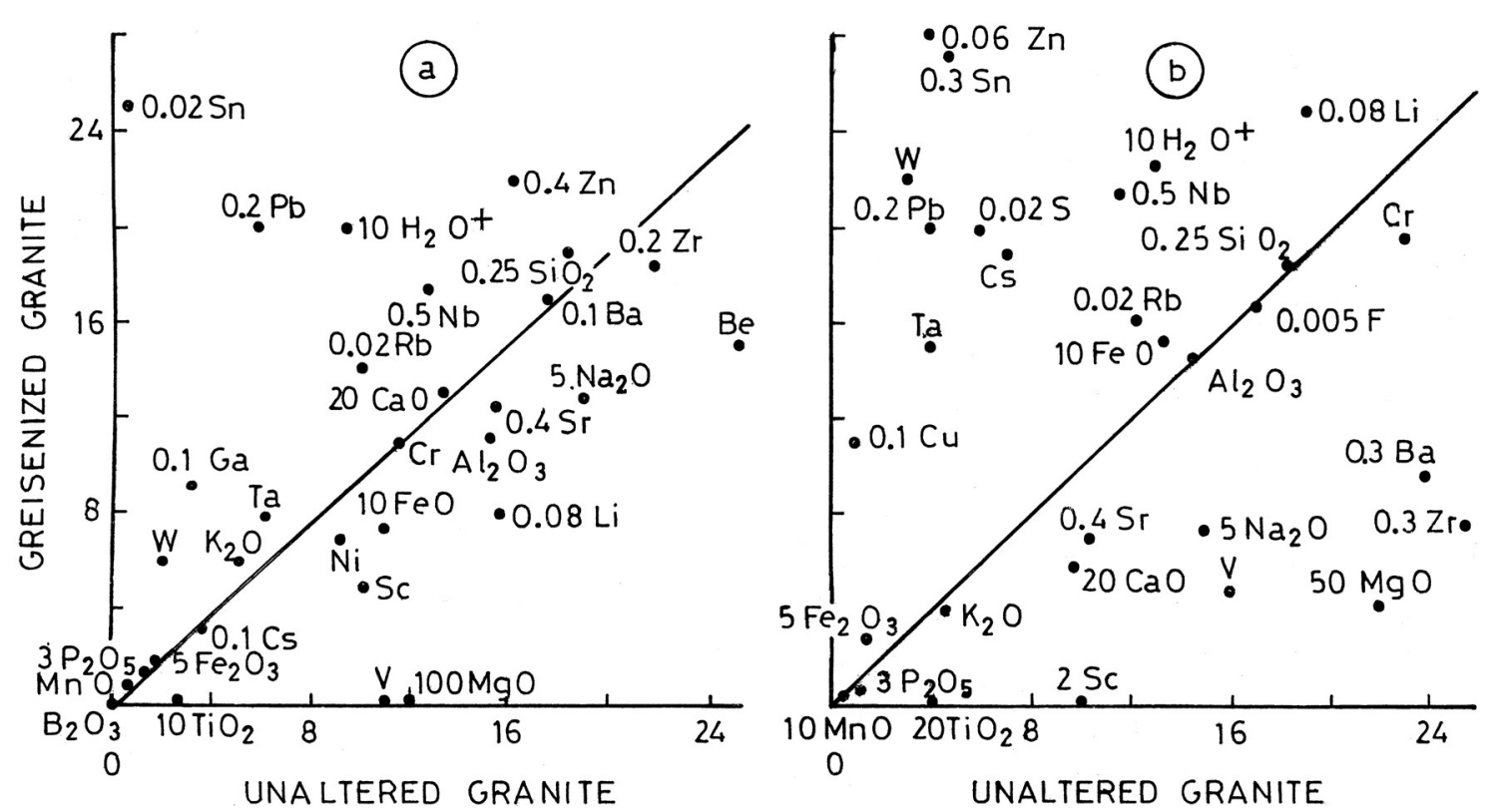

Fig. 9. Isocon diagrams comparing the unaltered granites and greisenized granites from a) S. Mamede de Ribatua (Alijó) and from b) Panasqueira. Oxides in wt.\% and elements in ppm. The deviation of a data point from the isocon defines the concentration change for the corresponding component.

and tin-tungsten quartz veins, while at Panasqueira tungsten-tin quartz veins, with wolframite as the main economic ore mineral and cassiterite occuring only in minor quantities, are related to the greisenized granite. The unaltered granites are peraluminous with A/CNK of 1.33 at S. Mamede de Ribatua and 1.20 at Panasqueira (Neiva 1987). Data are presented in Table 3, analyses 1a and 2a. Compared to the unaltered granite of S. Mamede de Ribatua, the unaltered granite from Panasqueira is less enriched in LREE with respect to HREE and has lower $\sum$ REE, fractionation within HREE and negative Eu anomaly (Fig. 8a). The granite has $\delta^{18} \mathrm{O}$ of $10 \%$ at Panasqueira (Bussink et al. 1984). The unaltered granites have 18 ppm Sn and $2 \mathrm{ppm} \mathrm{W}$ at S. Mamede de Ribatua, and $15 \mathrm{ppm}$ $\mathrm{Sn}$ and $3 \mathrm{ppm} \mathrm{W}$ at Panasqueira. Both granites have mineralogical and chemical characteristics of S-type granite (Chappell \& White 1992) which are confirmed by the isotopic data. They are probably derived by partial melting of sedimentary source materials (Neiva 1987).
The greisenized granites from both localities contain quartz, albite, K-feldspar, muscovite, ilmenite, zircon, apatite, arsenopyrite and pyrite. However at S. Mamede de Ribatua it also contains tourmaline, cassiterite, columbite-tantalite and galena, while at Panasqueira it has topaz, chalcopyrite and sphalerite. During greisenization there was an increase in quartz, and biotite, albite and K-feldspar were muscovitized. Greisenization was more intense at Panasqueira than at S. Mamede de Ribatua (Neiva 1987). Major and trace elements of greisenized granites are given in Table 3 (analyses $1 \mathrm{~b}$ and $2 \mathrm{~b}$ ). A whole-rock $\mathrm{Rb}-\mathrm{Sr}$ isochron yielded for the greisenized granite at Panasqueira an age of $289 \pm 4 \mathrm{Ma}(1 \sigma)$ with $\left({ }^{87} \mathrm{Sr} /\right.$ $\left.{ }^{86} \mathrm{Sr}\right)_{0}$ of $0.713 \pm 0.003$ (Priem \& Tex 1984). The age of greisenization determined by ${ }^{40} \mathrm{Ar} /{ }^{39} \mathrm{Ar}$ of muscovite is $292.1 \pm 0.4 \mathrm{Ma}$, which probably represents the time of resetting of earlier muscovites in the greisenized granite (Snee et al. 1988). During greisenization at $\mathrm{S}$. Mamede de Ribatua and Panasqueira, $\mathrm{SiO}_{2}, \mathrm{H}_{2} \mathrm{O}^{+}, \mathrm{Sn}, \mathrm{W}, \mathrm{Nb}, \mathrm{Ta}, \mathrm{Rb}, \mathrm{Zn}$, 
$\mathrm{Pb}$ increased and $\mathrm{MgO}, \mathrm{Na}_{2} \mathrm{O}, \mathrm{V}, \mathrm{Sc}, \mathrm{Zr}$ and $\mathrm{Sr}$ decreased (Figs. 9a, b).

The greisenized granite of S. Mamede de Ribatua is associated with $\mathrm{Sn}>\mathrm{W}$ mineralization and is richer in $\mathrm{Sn}(1250 \mathrm{ppm})$ and poorer in $\mathrm{W}(6$ ppm) than the greisenized granite of Panasqueira that is associated with $\mathrm{W}>\mathrm{Sn}$ mineralization and is richer in W (22 ppm) and poorer in Sn (92 ppm). In the greisenized granite of S. Mamede de Ribatua, Sn is mainly retained in cassiterite, and hydrothermal muscovite has a higher Sn content than primary muscovite in the unaltered granite (Table 3). At Panasqueira, Sn of greisenized granite is mainly retained in hydrothermal muscovite, which has a higher Sn content than primary muscovite of the parent granite. At S. Mamede de Rib- atua, hydrothermal muscovite has higher W content than primary muscovite, while at Panasqueira both muscovites have similar, highest $\mathrm{W}$ contents (Table 3 ).

\section{THE GRANITIC ROCKS AND GOLD- QUARTZ VEINS FROM THE JALES AREA}

Gold has been mined in the Jales area, in northern Portugal (Fig. 10). Long quartz veins of elongated lenticular structure, containing sulphides, sulphosalts, gold, electrum, and aurian silver, fill faults associated with the last Hercynian phase. Gold, electrum and aurian silver form inclusions in arsenopyrite, pyrite, galena, sphalerite, pyrrho-
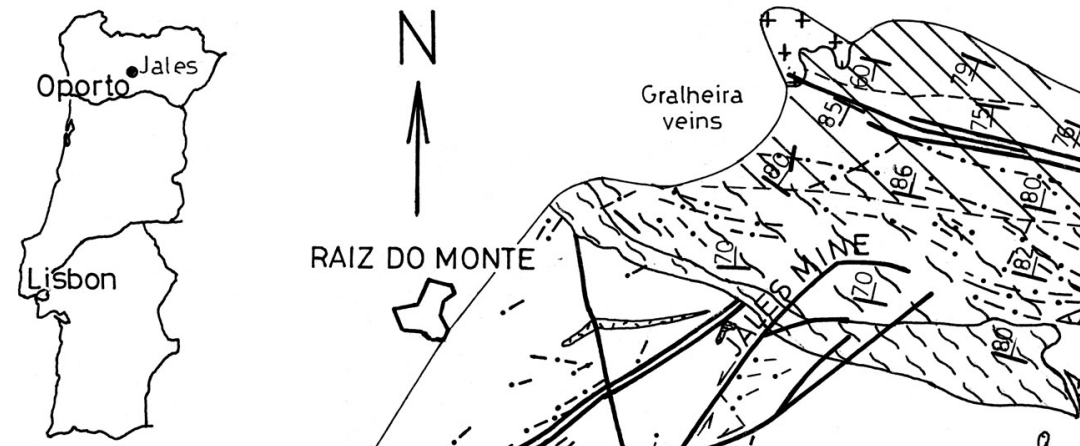

So*.:- $: 20$
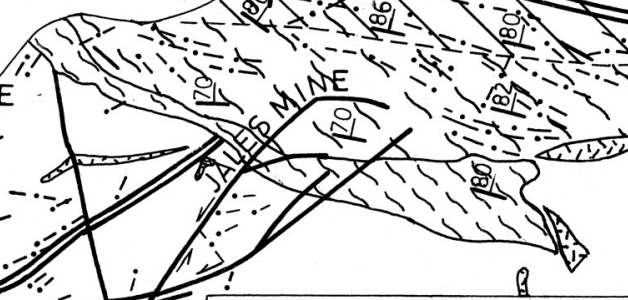

RAIZ DO MONTE
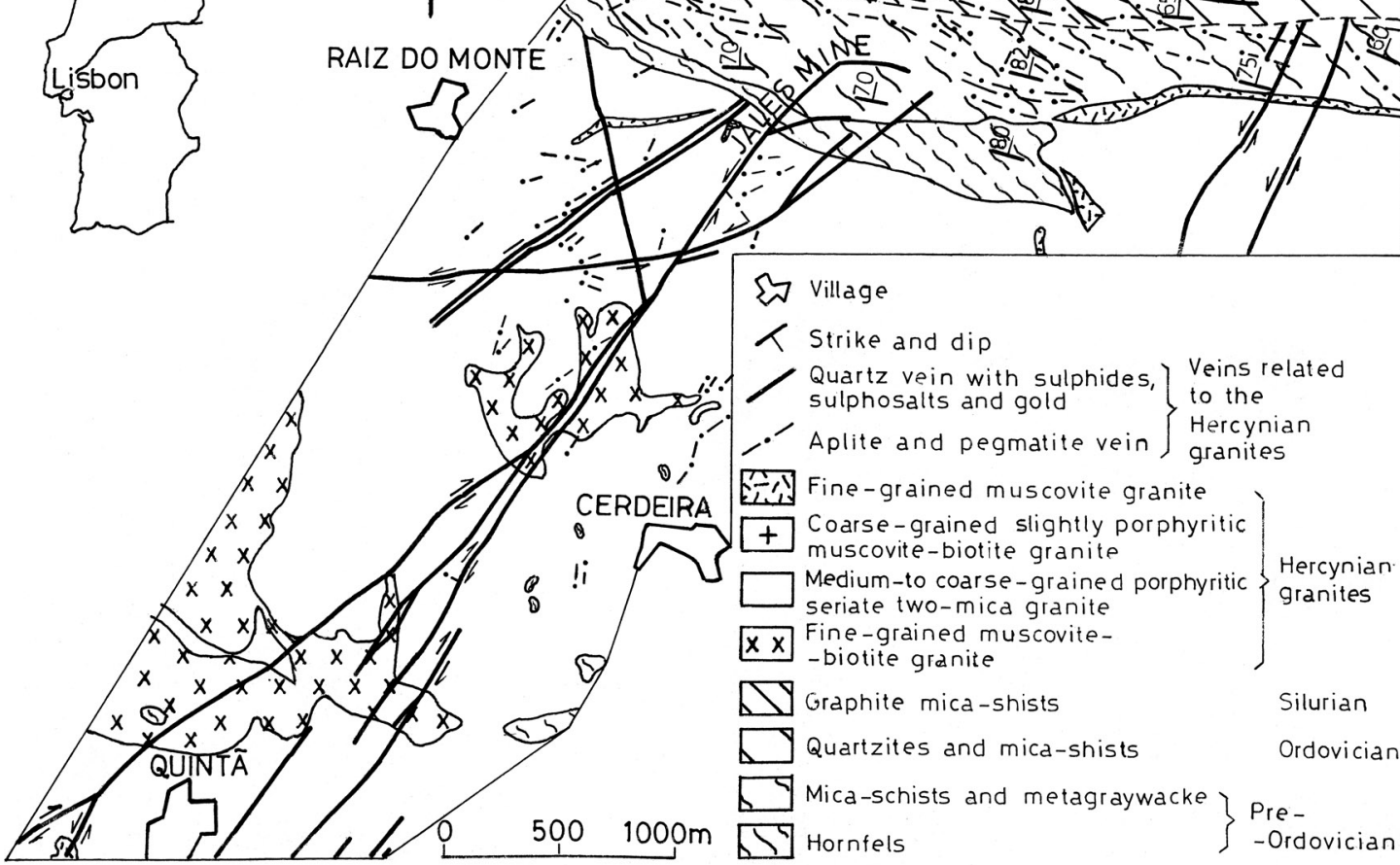

Sv village

Strike and dip

Quartz vein with sulphides, Veins related sulphosalts and gold to the Aplite and pegmatite vein $\left\{\begin{array}{l}\text { Hercynian } \\ \text { granites }\end{array}\right.$ Fine-grained muscovite granite Coarse-grained slightly porphyritic muscovite-biotite granite

Medium-to coarse-grained porphyritic Hercynian seriate two-mica granite

$x \times$ Fine-grained muscovite-

$\triangle$ Graphite mica-shists granites

$\square$ Quartzites and mica-shists

Silurian

Mica-schists and metagraywacke Horntels

Fig. 10. Location (inset, top left) and geological map of the Jales gold area, northern Portugal. 
tite and quartz and they also occur in veinlets that cut these minerals. Combined reserves comprise 1400000 tons ore with $12.9 \mathrm{~g} / \mathrm{t} \mathrm{Au}$ (equivalent to 18 tons $\mathrm{Au}$ ) in the Campo and Desvio veins, with 20 tons $\mathrm{Au}$ in the extension of the Campo vein to the SSW of the exploited area, 20 tons Au in the unexploited Capelas do Campo veins, and 20 tons $\mathrm{Au}$ in the unexploited Gralheira veins (Cotelo Neiva \& Neiva 1990).

The gold-quartz veins occur mainly in a medium- to coarse-grained porphyritic seriate two-mica granite, but they intersect pre-Ordovician and Ordovician mica schists (Fig. 10). A fine-grained muscovite-biotite granite is the oldest with an age of $320 \pm 6(1 \sigma)$ Ma determined by whole-rock Rb$\mathrm{Sr}$ isochron (Neiva et al. 1995). It is surrounded by the medium- to coarse-grained porphyritic seriate two-mica granite, which passes laterally to a coarse-grained slightly porphyritic muscovite-biotite granite. A fine-grained muscovite granite occurs in veins and masses cutting the porphyritic seriate two-mica granite and at some contacts between this granite and the pre-Ordovician mica schists. Aplite, aplite-pegmatite and pegmatite veins cut the mica schists, porphyritic seriate twomica granite and coarse-grained muscovite-biotite granite.

\section{Magmatic characteristics of the main granite associated with Au mineralization at the Jales mine}

The porphyritic seriate two-mica granite has phenocrysts of microcline and oligoclase-albite $\left(\mathrm{An}_{19}-\right.$ $\mathrm{An}_{6}$ ). The matrix contains quartz, microcline, oligoclase-albite $\left(\mathrm{An}_{14}-\mathrm{An}_{6}\right)$, equal amounts of $\mathrm{Fe}^{2+}-$ biotite and primary muscovite, schorl, apatite, monazite, ilmenite and rutile. It has $\mathrm{f}_{\mathrm{O}_{2}}$ lower than that of $\mathrm{Ni}-\mathrm{NiO}$ buffer and is peraluminous with $\mathrm{A} / \mathrm{CNK}$ of $1.15-1.49$. It has a high initial ${ }^{87} \mathrm{Sr} /{ }^{86} \mathrm{Sr}$ ratio of $0.7191 \pm 0.0008(1 \sigma)$ defined from a whole-rock $\mathrm{Rb}-\mathrm{Sr}$ isochron, which yields an age of $292 \pm 6 \mathrm{Ma}$. This is not a reliable result, because $\mathrm{Rb}-\mathrm{Sr}$ ages of $308.5 \pm 2.4(1 \sigma) \mathrm{Ma}$ are derived from muscovite - whole-rock and $294.5 \pm 1.1(1 \sigma)$ Ma from biotite - whole-rock pairs (Neiva et al.
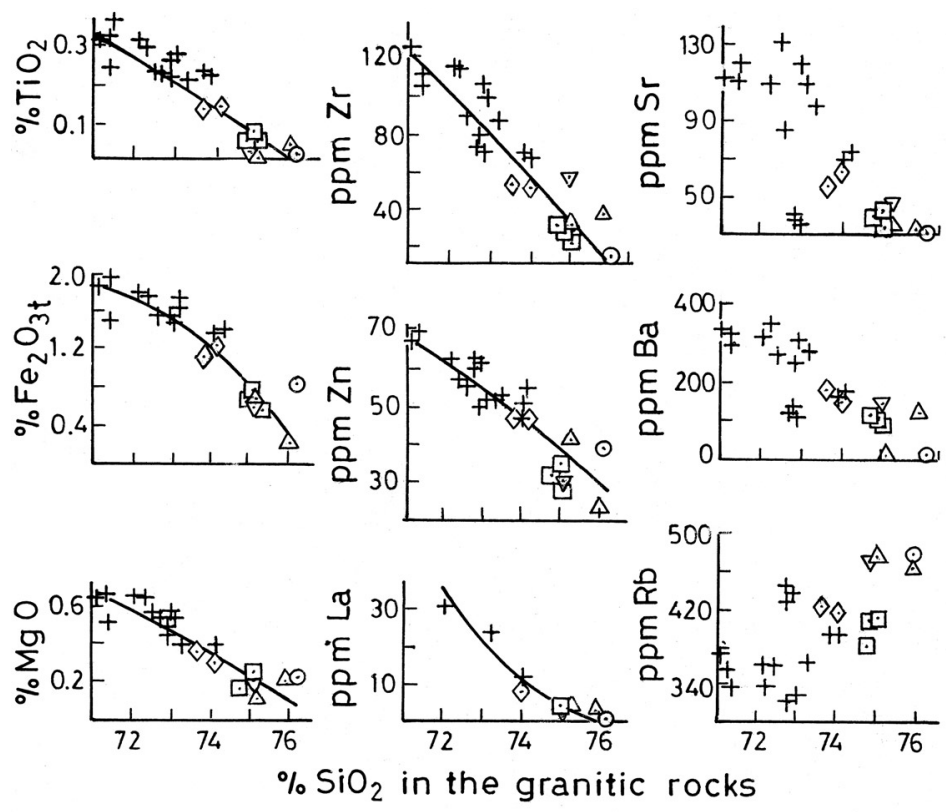

+-seriate two-mica granite,

$\vartheta$-muscovite-biotite granite, $\square$-muscovite granite,

$\nabla$-aplite-pegmatite vein, $\Delta$-aplite vein, $\odot$-pegmatite vein
Fig. 11. Selected variation diagrams of oxides and trace elements of the Jales granitic suite. 
Table 4. Chemical analyses, trace and rare earth elements of some granitic rocks from the Jales area.

\begin{tabular}{|c|c|c|c|c|c|c|c|c|c|}
\hline & $1 \mathrm{a}$ & $1 \mathrm{~b}$ & 2 & 3 & 4 & 5 & 6 & 7 & 8 \\
\hline $\mathrm{SiO}_{2}, \mathrm{wt} \%$ & 72.10 & 72.95 & 73.89 & 74.96 & 75.06 & 75.95 & 76.13 & 74.89 & 75.02 \\
\hline $\mathrm{TiO}_{2}$ & 0.29 & 0.20 & 0.14 & 0.04 & 0.01 & 0.04 & -- & 0.12 & 0.14 \\
\hline $\mathrm{Al}_{2} \mathrm{O}_{3}$ & 15.26 & 15.46 & 14.64 & 14.80 & 13.73 & 13.89 & 14.62 & 14.42 & 13.20 \\
\hline $\mathrm{Fe}_{2} \mathrm{O}_{3}$ & 0.33 & 0.34 & 0.33 & 0.03 & 0.30 & 0.04 & 0.33 & 0.33 & 0.56 \\
\hline $\mathrm{FeO}$ & 1.28 & 0.98 & 0.77 & 0.52 & 0.26 & 0.19 & 0.40 & 0.33 & 0.79 \\
\hline $\mathrm{MnO}$ & 0.04 & 0.01 & 0.04 & 0.02 & 0.08 & 0.06 & 0.06 & 0.06 & 0.08 \\
\hline $\mathrm{MgO}$ & 0.60 & 0.46 & 0.33 & 0.20 & 0.19 & 0.19 & 0.19 & 0.41 & 0.37 \\
\hline $\mathrm{CaO}$ & 0.85 & 0.59 & 0.50 & 0.43 & 0.38 & 0.36 & 0.30 & 0.24 & 0.23 \\
\hline $\mathrm{Na}_{2} \mathrm{O}$ & 3.16 & 3.07 & 3.28 & 3.59 & 2.01 & 3.61 & 3.67 & 2.76 & 1.33 \\
\hline $\mathrm{K}_{2} \mathrm{O}$ & 4.97 & 4.84 & 4.87 & 4.33 & 7.27 & 4.80 & 4.10 & 5.52 & 5.74 \\
\hline $\mathrm{P}_{2} \mathrm{O}_{5}$ & 0.26 & 0.30 & 0.35 & 0.27 & 0.26 & 0.15 & 0.22 & 0.16 & 0.17 \\
\hline $\mathrm{S}$ & 0.02 & 0.03 & 0.02 & 0.03 & 0.14 & 0.04 & 0.08 & 0.14 & 0.24 \\
\hline $\mathrm{H}_{2} \mathrm{O}^{+}$ & 0.68 & 0.77 & 0.83 & 0.51 & 0.32 & 0.37 & 0.56 & 0.72 & 0.97 \\
\hline $\mathrm{H}_{2} \mathrm{O}^{-}$ & 0.16 & 0.13 & 0.12 & 0.18 & 0.04 & 0.10 & 0.04 & 0.12 & 0.08 \\
\hline Total & 100.00 & 100.13 & 100.11 & 99.91 & 100.05 & 99.79 & 100.10 & 100.22 & 98.92 \\
\hline $\mathrm{F} \quad \mathrm{ppm}$ & 1214 & 1094 & 833 & 870 & 484 & 863 & 626 & 816 & 1159 \\
\hline $\mathrm{Cr}$ & 9 & 7 & 4 & 3 & $*$ & $*$ & $*$ & $<6$ & $<6$ \\
\hline $\mathrm{Nb}$ & 9 & 18 & 16 & 12 & 2 & 12 & 10 & 5 & 5 \\
\hline $\mathrm{Zn}$ & 59 & 57 & 47 & 32 & 30 & 27 & 40 & 56 & 160 \\
\hline $\mathrm{Sn}$ & 3 & 6 & 13 & 7 & * & 21 & 19 & 9 & 14 \\
\hline $\mathrm{Li}$ & 189 & 138 & 211 & 143 & 15 & 13 & 16 & 29 & 23 \\
\hline $\mathrm{Ni}$ & 10 & 12 & 11 & 10 & 7 & 2 & 7 & 4 & 4 \\
\hline $\mathrm{Zr}$ & 111 & 79 & 62 & 25 & 55 & 39 & 14 & 64 & 65 \\
\hline $\mathrm{Cu}$ & 10 & 6 & 9 & 7 & 104 & 17 & 13 & 26 & 37 \\
\hline $\mathrm{Sc}$ & $*$ & $*$ & $*$ & $*$ & 5 & 3 & 5 & $*$ & $*$ \\
\hline Y & 23 & 11 & 21 & 8 & 38 & 34 & 38 & 30 & 31 \\
\hline $\mathrm{Sr}$ & 115 & 69 & 61 & 37 & 43 & 33 & 30 & 51 & 48 \\
\hline $\mathrm{Pb}$ & 44 & 41 & 28 & 41 & 159 & 44 & 78 & 134 & 183 \\
\hline $\mathrm{Ba}$ & 316 & 191 & 153 & 103 & 133 & 123 & 12 & 150 & 141 \\
\hline $\mathrm{Rb}$ & 345 & 394 & 416 & 396 & 468 & 460 & 478 & 347 & 356 \\
\hline Cs & * & $*$ & 15 & $*$ & 5 & * & 13 & * & 6 \\
\hline As & 1.20 & 5.20 & 9.4 & 2.46 & 1271 & 24 & 138 & 282 & 20691 \\
\hline $\mathrm{Sb}$ & 0.19 & 0.14 & 0.29 & 0.11 & 4.40 & 0.07 & 0.44 & 0.37 & 6.40 \\
\hline $\mathrm{Ag}$ & 2.70 & 5.07 & $<2.3$ & $<6$ & 4.10 & $<2.6$ & $<2.6$ & 2.30 & 2.40 \\
\hline $\mathrm{Au} \mathrm{ppb}$ & 6.90 & 7.10 & $<6.8$ & $<4.7$ & 1710 & 7.40 & 7.50 & 9.70 & 59.60 \\
\hline La ppm & 32.33 & 18.23 & 8.33 & 3.74 & 3.26 & 4.08 & 0.85 & 14.65 & 9.22 \\
\hline $\mathrm{Ce}$ & 72.19 & 37.62 & 20.35 & 8.87 & 7.41 & 10.28 & 2.10 & 39.25 & 19.06 \\
\hline $\mathrm{Nd}$ & 30.07 & 17.02 & 10.56 & 5.12 & 3.20 & 4.03 & 0.96 & 16.01 & 9.14 \\
\hline $\mathrm{Sm}$ & 5.09 & 2.82 & 2.26 & 0.93 & 0.53 & 0.64 & 0.18 & 2.64 & 1.69 \\
\hline $\mathrm{Eu}$ & 0.86 & 0.43 & 0.30 & 0.20 & 0.06 & 0.09 & 0.02 & 0.52 & 0.28 \\
\hline $\mathrm{Gd}$ & 3.63 & 2.30 & 2.08 & 1.04 & 0.43 & 0.64 & 0.29 & 2.30 & 1.33 \\
\hline $\mathrm{Tb}$ & 0.66 & 0.42 & 0.36 & $<0.30$ & 0.08 & 0.12 & 0.06 & 0.51 & 0.24 \\
\hline $\mathrm{Yb}$ & 1.18 & 0.93 & 0.75 & 0.83 & 0.28 & 0.35 & 0.21 & 1.02 & 0.63 \\
\hline $\mathrm{Lu}$ & 0.14 & 0.11 & 0.09 & 0.10 & 0.04 & 0.05 & 0.03 & 0.11 & 0.07 \\
\hline
\end{tabular}

1- medium to coarse-grained porphyritic seriate two-mica granite, a- least silicic samples, b- the most silicic samples;

2- coarse-grained slightly porphyritic muscovite-biotite granite; 3- fine-grained muscovite granite; 4- aplite-pegmatite; 5- aplite; 6- pegmatite; 7 and 8- hydrothermally altered granites in the Campo gold-quartz vein walls, 7- medium-to coarse-grained porphyritic muscovite-biotite granite at $0.5-1 \mathrm{~m}$ from the vein, 8 - medium- to coarse-grained muscovite granite at the direct contact with the vein. - not detected, n.d. - not determined, * - below the limit of sensitivity. Analyses by A. Neiva. 


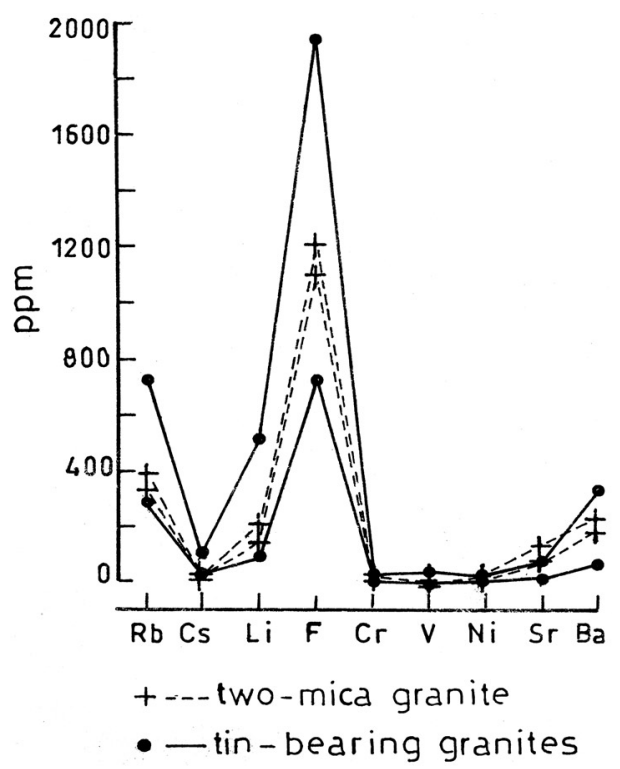

Fig. 12. Comparison of contents of selected trace elements in the medium-to coarse-grained porphyritic seriate two-mica granite from Jales with those in Portuguese tin-bearing granites.

1995). On the basis of these dates and the field relationship with the oldest granite, it is assumed that the porphyritic seriate two-mica granite was emplaced between $320 \pm 6$ and $308.5 \pm 2.4$ Ma. It has chemical and isotopic characteristics of Stype granite.

Geochemical evidences of whole-rocks and their biotites and muscovites show that the oldest muscovite-biotite granite and the porphyritic seriate two-mica granite are not related genetically (Neiva \& Gomes 1991). Their distinct initial Sr isotope ratios $(0.7159 \pm 0.0012$ and $0.7191 \pm$ 0.0008 , respectively), yielded by whole-rock RbSr isochrons (Neiva et al. 1995), also confirm that they are not comagmatic and suggest that they were generated from partial melting of metasedimentary source materials.

The porphyritic seriate two-mica granite, coarse-grained muscovite-biotite granite, muscovite granite, as well as aplite-pegmatite, aplite and pegmatite veins are highly peraluminous with $\mathrm{A} /$ CNK of 1.15-1.50 and show fractionation trends for oxides and trace elements (Fig. 11 and Table 4). Their chondrite-normalized rare earth patterns are generally subparallel and enriched in LREE with respect to HREE (Fig. 8b). There is a general decrease in $\sum$ REE and increase in Eu negative anomaly from the seriate two-mica granite to the pegmatite vein. However, some of the most silicic samples of the porphyritic seriate two-mica granite, coarse-grained muscovite-biotite granite and muscovite granite, as well as one aplite and one pegmatite vein have lower $\mathrm{Sr}$ and $\mathrm{Ba}$ and higher Rb (Fig. 11) due to some minor metasomatic effects, which also affected REE of the muscovite granite (Fig. 8b). The least silicic samples of the porphyritic seriate two-mica granite represent the parent magma. The other granitic rocks are derived by fractional crystallization of plagioclase, biotite and quartz, but also of muscovite and K-feldspar for the last differentiates as shown by Neiva (1992).

The porphyritic seriate two-mica granite has a low $\mathrm{Sn}$ content of $3 \mathrm{ppm}$ in the least silicic samples and $6 \mathrm{ppm}$ in the most silicic samples. Tin increases during fractional crystallization reaching 19-21 ppm in the aplite and pegmatite veins.

Gold content is of $6.9 \mathrm{ppb}$ in the least silicic samples of the porphyritic seriate two-mica granite, but reaches $1710 \mathrm{ppb}$ in the aplite-pegmatite vein, which is also the richest in As (1271 ppm). The gold-quartz veins may have been formed from hydrothermal fluids of late stages of fractional crystallization of the porphyritic seriate two-mica granite (Cotelo Neiva \& Neiva 1990, Neiva 1992). The process is complex and probably other fluids circulating through the schists may also have been involved. However, Au and Ag were not detected in the unaltered pre-Ordovician mica schist (Neiva et al. 1990). Therefore, the mica schist appears not to be the direct source of gold and silver. Some silicates and graphite of pelitic sediments may have contained small amounts of these metals. The S-type granite was derived by partial melting of large volumes of these sediments, and $\mathrm{Au}$ and Ag may have been concentrated in the residual liquid (Cotelo Neiva \& Neiva 1990).

The porphyritic seriate two-mica granite is enriched in $\mathrm{Rb}, \mathrm{Cs}, \mathrm{Li}$, and $\mathrm{F}$ and impoverished in $\mathrm{Cr}, \mathrm{V}, \mathrm{Ni}, \mathrm{Sr}$, and $\mathrm{Ba}$ like the tin-bearing granites (Fig. 12), but it has a low Sn content. 


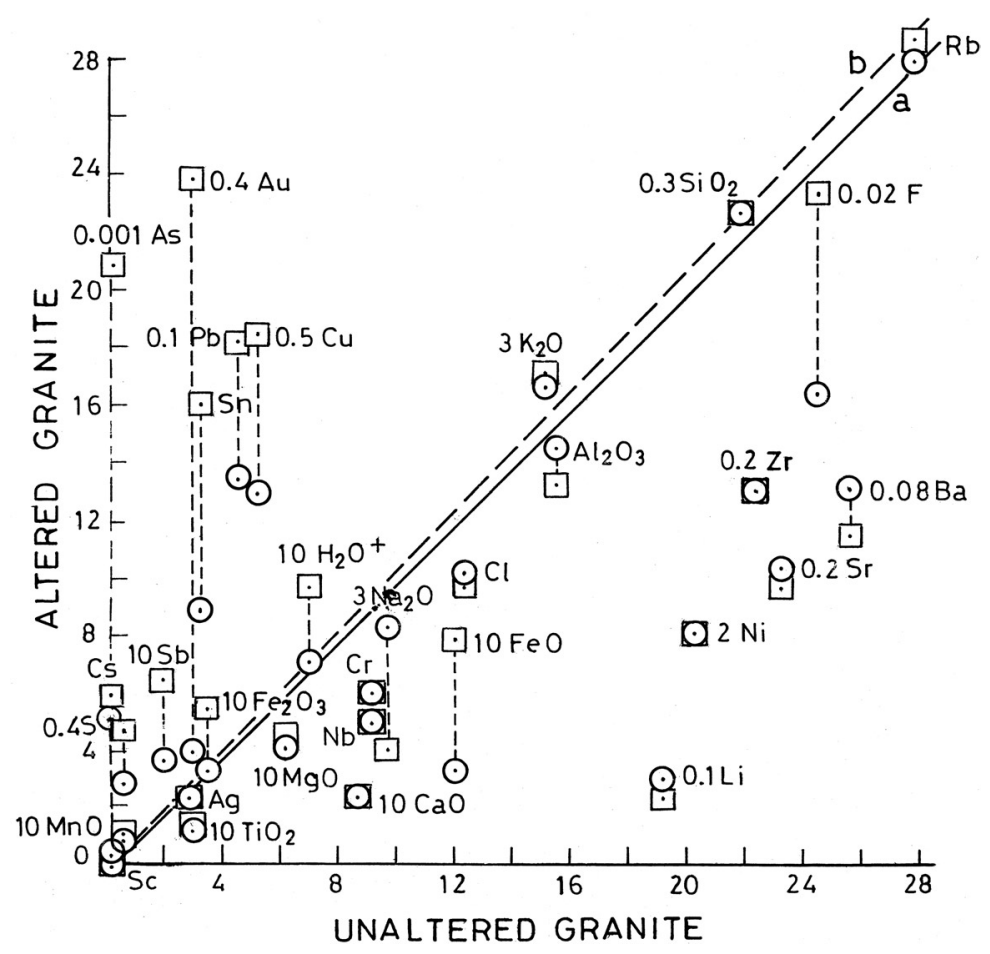

Fig. 13. Isocon diagram comparing unaltered two-mica granite from Jales with the hydrothermally altered muscovite-biotite granite $(\odot)$ and muscovite granite $(\square)$ along the Campo (Jales) goldquartz vein walls. Oxides in wt.\%, elements in ppm, except Au in ppb. The lines show isocons (a for muscovite-biotite granite, $b$ for muscovite granite). The dashed lines show the progressive changes due to gain and loss of components.

\section{HYDROTHERMAL ALTERATION OF THE GRANITE ALONG THE CAMPO GOLD- QUARTZ VEIN AT JALES}

The unaltered porphyritic seriate two-mica granite was hydrothermally altered along the Campo gold-quartz vein. It was transformed to a porphyritic muscovite-biotite granite in an outer zone at $0.5-1 \mathrm{~m}$ from the gold-quartz vein and to a muscovite granite in an inner zone up to $0.5 \mathrm{~m}$ from the vein. The granite became enriched in quartz, microcline, muscovite, and sulphides, and impoverished in plagioclase and biotite (Neiva et al. 1990).

During the hydrothermal alteration there was a progressive increase in $\mathrm{K}_{2} \mathrm{O}, \mathrm{H}_{2} \mathrm{O}^{+}, \mathrm{Cu}, \mathrm{Sn}, \mathrm{Pb}$, $\mathrm{Au}, \mathrm{Sb}, \mathrm{S}, \mathrm{Cs}$, and $\mathrm{As}$, and progressive decrease in $\mathrm{Ba}, \mathrm{Sr}, \mathrm{Li}, \mathrm{Al}_{2} \mathrm{O}_{3}, \mathrm{Cl}$, and $\mathrm{Na}_{2} \mathrm{O}$ towards the direct contact with the gold-quartz veins (Fig. 13). The increases in $\mathrm{S}, \mathrm{Sb}, \mathrm{As}, \mathrm{Cu}, \mathrm{Pb}$ and $\mathrm{Au}$ are due to the formation of increasing amounts of sulphides, sulphosalts and gold. The increases in $\mathrm{K}_{2} \mathrm{O}, \mathrm{H}_{2} \mathrm{O}^{+}$and $\mathrm{Sn}$ are explained by crystallization of later muscovite, but the increase in $\mathrm{K}_{2} \mathrm{O}$ can also be attributed to formation of later K-feldspar. The losses in $\mathrm{Sr}, \mathrm{Al}_{2} \mathrm{O}_{3}$ and $\mathrm{Na}_{2} \mathrm{O}$ are due to a decrease in plagioclase content, and the losses in $\mathrm{Li}$, $\mathrm{Cl}$ and $\mathrm{Al}_{2} \mathrm{O}_{3}$ are attributed to a decrease in the amount of biotite.

The hydrothermally altered porphyritic muscovite-biotite granite at $0.5-1 \mathrm{~m}$ from the Campo gold-quartz vein has a REE pattern that overlaps those of the most silicic samples of the unaltered porphyritic two-mica granite (Fig. 8c). However, the muscovite granite adjacent to the gold-quartz vein is depleted in all REE probably due to a decrease in the amounts of monazite (for LREE), apatite (for MREE and HREE) and zircon (for HREE) (Bea et al. 1996).

The pairs of muscovite and microclinised albite of the altered granite in direct contact with the Campo gold-quartz vein gave a weighted mean $\mathrm{Rb}-\mathrm{Sr}$ age of $300.8 \pm 1.5 \mathrm{Ma}$, and a ${ }^{39} \mathrm{Ar}-{ }^{40} \mathrm{Ar}$ analysis of this muscovite gave a mean age of 300.7 \pm $2.8 \mathrm{Ma}$. Taking into account the $\mathrm{Rb}-\mathrm{Sr}$ age (308.5 $\pm 2.4 \mathrm{Ma}$ ) of primary muscovite from unaltered 
granite, the data suggest that circulation of gold mineralising fluids took place no more than 2-4 Ma after the granite cooled through the muscovite $\mathrm{Rb}$-Sr closure temperature at about $500^{\circ} \mathrm{C}$. A subsequent cooling to biotite closure at about $300^{\circ} \mathrm{C}$ took place at a cooling rate less than $14^{\circ} \mathrm{C} / \mathrm{Ma}$. The granite emplacement, mineralization of the Campo gold-quartz vein and subsequent cooling to $300^{\circ} \mathrm{C}$ took place during 15 to $25 \mathrm{Ma}$ with a mean cooling rate of 15 to $25^{\circ} \mathrm{C} / \mathrm{Ma}$ (Neiva et al. 1995).

\section{CONCLUSIONS}

1) The Portuguese Hercynian granites associated with tin-tungsten deposits are 336-287 Ma old strongly differentiated muscovite-biotite granites and muscovite granites, enriched in $\mathrm{Sn}, \mathrm{Rb}$, $\mathrm{Cs}, \mathrm{Li}$, and $\mathrm{F}$, and impoverished in $\mathrm{Ti}, \mathrm{Cr}, \mathrm{V}$, $\mathrm{Ni}, \mathrm{Co}, \mathrm{Sr}$, and $\mathrm{Ba}$. They are peraluminous (A/ $\mathrm{CNK} \geq 1.1$ ) and have a negative Eu anomaly. They show isotopic values $\left({ }^{87} \mathrm{Sr} /{ }^{86} \mathrm{Sr}\right)_{0} \geq 0.708$, $\varepsilon_{\mathrm{Nd}}(\mathrm{T})$ of -4.5 to -16.4 and $\delta^{18} \mathrm{O}$ of $11.0_{-}$ $12.8 \%$. These rocks are S-type granites generated by partial melting of heterogeneous metasedimentary materials. They commonly contain 18-100 ppm Sn and 3-9 ppm W. Generally, muscovite retains a higher percentage of total granite tin than biotite.

2) Three fractionation suites of tin-bearing S-type Hercynian granites were found in northern and central Portugal. Two of them range from muscovite-biotite granite to muscovite granite and muscovite retains the highest percentage of total granite tin. The third suite ranges from aplite to microgranite, which probably represents a pegmatitic composition and contains cassiterite.

3) In northern and central Portugal, there are also other tin-bearing granites with $28-40 \mathrm{ppm} \mathrm{Sn}$ and up to $13 \mathrm{ppm} \mathrm{W}$, which are less evolved than the tin-bearing S-type granites. They are of 357-308 Ma age and have a negative $\mathrm{Eu}$ anomaly. Some are two-mica granites and biotite granites with A/CNK of $1.05-1.36,\left({ }^{87} \mathrm{Sr} /\right.$ $\left.{ }^{86} \mathrm{Sr}\right)_{0}$ of $0.707-0.709$ and $\varepsilon_{\mathrm{Nd}}(\mathrm{T})$ of -2.9 to
-5.6 , and they have mixed characteristics of Itype and S-type granites. Quartz veins with scheelite $>$ cassiterite are rarely associated with them. There are also other tin-bearing biotite granites, with $\mathrm{A} / \mathrm{CNK}$ of $0.98-1.10$, high $\mathrm{K}_{2} \mathrm{O}$, $\left({ }^{87} \mathrm{Sr} /{ }^{86} \mathrm{Sr}\right)_{0}$ of 0.7044 and $\varepsilon_{\mathrm{Nd}}(\mathrm{T})$ of -0.8 , which show many characteristics of I-type granite. They are richer in $\sum$ REE and LREE and have a less pronounced negative Eu anomaly than the tin-bearing granites of S-type. However, tin-tungsten deposits are not known to be associated with these granites.

4) The peraluminous granites with an age of 303 $\pm 5 \mathrm{Ma}$ range from felsic granite to cordieritebiotite granite, and have A/CNK of 1.11-1.92 and Sn content of 26-53 ppm. They were generated by sequential higher extents of partial melting of orthogneiss with progressive less efficient segregation of restitic materials. $\sum$ REE, LREE, $\mathrm{La}_{\mathrm{N}} / \mathrm{Yb}_{\mathrm{N}}$ and negative Eu anomaly increase from felsic granite to cordierite-biotite granite. Tin and tungsten deposits are not known to be related to them.

5) The quartz veins with wolframite from Carris are associated with a $302 \pm 4$ Ma old peraluminous $(\mathrm{A} / \mathrm{CNK}=1.02-1.06)$ I-type biotite granite, which contains a large negative $\mathrm{Eu}$ anomaly, has $\left({ }^{87} \mathrm{Sr} /{ }^{86} \mathrm{Sr}\right)_{0}$ of $0.7052 \pm 0.0005$ and is of mantle origin.

6) Greisenizations of S-type two-mica granites from S. Mamede de Ribatua and Panasqueira are accompanied by enrichment in $\mathrm{SiO}_{2}, \mathrm{H}_{2} \mathrm{O}^{+}$, $\mathrm{Sn}, \mathrm{W}, \mathrm{Nb}, \mathrm{Ta}, \mathrm{Rb}, \mathrm{Zn}, \mathrm{Pb}$ and impoverishment in $\mathrm{MgO}, \mathrm{Na}_{2} \mathrm{O}, \mathrm{V}, \mathrm{Sc}, \mathrm{Zr}$ and $\mathrm{Sr}$. Tin > tungsten mineralization is associated with the greisenized granite from S. Mamede de Ribatua, which has the highest Sn content (mainly retained in cassiterite). The greisenized granite from Panasqueira is associated with tungsten $>$ tin mineralization and is the richest in $\mathrm{W}$. Tin is mainly retained in hydrothermal muscovite.

7) The granite associated with the Jales gold deposit is a $320 \pm 6$ to $308.5 \pm 2.4$ Ma old, twomica granite with equal amounts of both micas. It is strongly differentiated, peraluminous $(\mathrm{A} / \mathrm{CNK}=1.15-1.49)$, enriched in $\mathrm{Rb}, \mathrm{Cs}, \mathrm{Li}$, and $\mathrm{F}$, and impoverished in $\mathrm{Ti}, \mathrm{Cr}, \mathrm{V}, \mathrm{Ni}, \mathrm{Co}$, 
$\mathrm{Sr}$, and $\mathrm{Ba}$. The granite shows a negative $\mathrm{Eu}$ anomaly, contains up to $7.1 \mathrm{ppb} \mathrm{Au}$, and the isotopic value $\left({ }^{87} \mathrm{Sr} /{ }^{86} \mathrm{Sr}\right)_{0}$ is $0.7191 \pm 0.0008$ $(1 \sigma)$. It is a $S$-type granite originated by partial melting of metasedimentary materials.

8) At Jales, the gold-quartz veins are hosted by a two-mica granite which represents the parent magma of a granitic suite ranging to pegmatite. This suite shows an increase in $\mathrm{Sn}$ from 3 to $21 \mathrm{ppm}$ and in Au from 6.9 to $1710 \mathrm{ppb}$.

9) The progressive hydrothermal alteration of the S-type two-mica granite along the Campo (Jales) gold quartz vein walls was accompanied by a progressive enrichment in $\mathrm{K}_{2} \mathrm{O}, \mathrm{H}_{2} \mathrm{O}^{+}, \mathrm{Cu}$, $\mathrm{Pb}, \mathrm{Sn}, \mathrm{As}, \mathrm{Au}, \mathrm{Sb}, \mathrm{S}$, and $\mathrm{Cs}$, and progressive decrease in $\mathrm{Al}_{2} \mathrm{O}_{3}, \mathrm{Na}_{2} \mathrm{O}, \mathrm{Cl}, \mathrm{Ba}, \mathrm{Sr}$, and $\mathrm{Li}$. The muscovite granite adjacent to the Campo gold-quartz vein is impoverished in all REE.

ACKNOWLEDGEMENTS. Thanks are due to Prof. S. Ishihara and Prof. J. Tarney for the helpful comments as well as to Prof. I. Haapala and Dr. Y. Kähkönen for the editorial revisions. This research work was carried out in a programme of the Geosciences Centre of Coimbra University.

\section{REFERENCES}

Almeida, A., Noronha, F. \& Leterrier, J. 1995. Estudo geoquímico do complexo granítico de Cabeceiras de Basto: implicações petrogenéticas e metalogénicas. Museu e Laboratório Mineralógico e Geológico, Universidade do Porto 4, 687-691.

Bea, F. 1996. Residence of REE, Y, Th and U in granites and crustal protoliths: implications for the chemistry of crustal melts. Journal of Petrology 37, 521-552.

Biste, M. 1979. Die Anwendung geochemischer Indikatoren auf die Zinn-Hoeffigkeit herznishcer granite in Sued-Sardinien. Berliner Geowissenschaften Abhandlungen 18, 1-109.

Blevin, P.L. \& Chappell, B.W. 1992. The role of magma sources, oxidation states and fractionation in determining the granite metallogeny of Eastern Australia. Transactions of the Royal Society of Edinburgh, Earth Sciences 83, 305-316.

Bussink, R.W., Kreulen, R. \& De Yong, A.F.M. 1984. Gas analyses, fluid inclusions and stable isotopes of the Panasqueira W-Sn deposits, Portugal.Bulletin de Minéralogie 107, 703-714.
Carneiro, F.S. 1959. A riqueza da indústria extractiva metropolitana. Estudos, Notas e Trabalhos do Serviço de Fomento Mineiro 13, 65-215.

Chappell, B.W. \& White, A.J.R. 1992. I and S-type granites in the Lachlan Fold Belt. Transactions of the Royal Society of Edinburgh, Earth Sciences 83, 1-26.

Charoy, B. \& Noronha, F. 1996. Multistage growth of a rare-element volatile-rich microgranite at Argemela (Portugal). Journal of Petrology 37, 73-94.

Cole, A., Wilkinson, Y.Y., Halls, C. \& Serenko, T.J. 2000. Geological characteristics, tectonic setting and preliminary interpretations of the Jilan gold-quartz vein deposit, Tajikistan. Mineralium Deposita 35, 600-618.

Collins, W.J., Beams, S.D., White, A.J.R. \& Chappell, B.W. 1982. Nature and origin of A-type granites with particular reference to Southeastern Australia. Contributions to Mineralogy and Petrology 80, 189-200.

Cotelo Neiva, J.M. 1944. Jazigos portugueses de cassiterite e de volframite. Comunicações dos Serviços Geológicos de Portugal 25, 1-251.

Cotelo Neiva, J.M. 1972. Tin-tungsten deposits and granites from northern Portugal. 24 ${ }^{\text {th }}$ International Geological Congress, Montreal, Section 4, 282-288.

Cotelo Neiva, J.M. \& Neiva, A.M.R. 1990. The gold area of Jales (northern Portugal). Terra Nova 2, 243-254.

El Bouseily, A.M. \& El Sokkary, A.A. 1975. The relation between $\mathrm{Rb}, \mathrm{Ba}$ and $\mathrm{Sr}$ in granitic rocks. Chemical $\mathrm{Ge}-$ ology 16, 207-220.

Eugster, H. 1985. Granites and hydrothermal ore deposits: a geochemical framework. Mineralogical Magazine 49, 7-23.

Gomes, M.E.P. 1996. Mineralogia, petrologia e geoquímica das rochas granitóides da área de Rebordelo-BouçaTorre de D. Chama-Agrochão e as mineralizações associadas. Unpublished Ph.D. thesis, University of Trásos-Montes e Alto-Douro, 323 p.

Gomes, M.E.P. \& Neiva, A.M.R. 2000. Chemical zoning of muscovite from the Ervedosa granite, northern Portugal. Mineralogical Magazine 64, 347-358.

Gomes, M.E.P. \& Neiva, A.M.R. 2002. Petrogenesis of tinbearing granites from Ervedosa, northern Portugal: the importance of magmatic processes. Chemie der Erde 62, 47-72.

Haapala, I. 1997. Magmatic and postmagmatic processes in tin-mineralized granites: topaz-bearing leucogranite in the Eurajoki rapakivi granite stock, Finland. Journal of Petrology 38, 1645-1659.

Heinrich, C.A. 1990. The chemistry of hydrothermal tin (-tungsten) ore deposition. Economic Geology 85, 457481.

Holtz, F. \& Barbey, P. 1991. Genesis of peraluminous granites. II. Mineralogy and chemistry of the Tourém complex (North Portugal). Sequential melting vs. restite unmixing. Journal of Petrology 32, 959-978.

Holtz, F. \& Juteau, M. 1987. Indications géochronologiques des minéraux accessories, monazites et zircons, sur la migmatisation Hercynienne de la Péninsule Ibérique. Migmatites et orthogneiss de Tourém (Nord Portugal). Comptes Rendus Academie Sciences Paris 304, 713717. 
Ishihara, S., Sawata, H., Shibata, K., Terashima, S., Arrykul, S. \& Sato, K. 1980. Granites and Sn-W deposits of Peninsular Thailand. In: Ishihara, S. \& Takenouchi, S. (eds.) Granitic magmatism and related mineralization. Mining Geology Special Issue 8, 223-242.

Lehmann, B. 1987. Tin granites, geochemical heritage, magmatic differentiation. Geologische Rundschau 76, 177-185.

Lehmann, B. 1990. Metallogeny of tin. Lecture Notes in Earth Sciences. Berlin: Springer-Verlag. 211 p.

McCoy, D., Newberry, R.J., Layer, P., DiMarchi, J.J., Bakke, A., Masterman, S. \& Minehane, D.L. 1997. Plutonic-related gold deposits of Interior Alaska. In: Goldfarb, R.J. \& Miller, L.D. (eds.) Mineral deposits of Alaska. Economic Geology Monograph 9, 191-241.

Neiva, A.M.R. 1973. Geochemistry of the granites and their minerals from the central area of northern Portugal. Memórias e Notícias do Museu e Laboratório Mineralógico e Geológico, Universidade de Coimbra 76, 1-43.

Neiva, A.M.R. 1974. Greisenization of a muscovite-biotite albite granite of northern Portugal. Chemical Geology 13, 295-308.

Neiva, A.M.R. 1975. Geochemistry of coexisting aplites and pegmatites and of their minerals from central northern Portugal. Chemical Geology 16, 153-177.

Neiva, A.M.R. 1983. Geochemistry of granitic rocks and their micas from the West border of the Alvão plateau, northern Portugal. Chemie der Erde 42, 31-44.

Neiva, A.M.R. 1984. Geochemistry of tin-bearing granitic rocks. Chemical Geology 43, 241-256.

Neiva, A.M.R. 1987. Geochemistry of greisenized granites and metasomatic schists of tungsten-tin deposits in Portugal. In: Helgeson, H.C. (ed.) Chemical Transport in Metasomatic Processes. NATO ASI Series C218, 681700.

Neiva, A.M.R. 1992. Geochemistry and evolution of Jales granitic system, northern Portugal. Chemie der Erde 52, 225-241.

Neiva, A.M.R. 1993. Geochemistry of granites and their minerals from Gerez mountain, Northern Portugal. Chemie der Erde 53, 227-258.

Neiva, A.M.R. 1994. Dating and geochemistry of tin-bearing granitic rocks and their minerals from NE of Gerez mountain, Northern Portugal. Boletín de la Sociedad Española de Mineralogía 17, 65-82.

Neiva, A.M.R. 1996. Geochemistry of cassiterite and its inclusions and exsolution products from tin and tungsten deposits in Portugal. Canadian Mineralogist 34, 745-768.

Neiva, A.M.R., Dodson, M.H., Rex, D.C. \& Guise, P.G. 1995. Radiometric constraints on hydrothermal circulation in cooling granite pluton. Mineralium Deposita 30, 460-468.

Neiva, A.M.R. \& Gomes, M.E.P. 1991. Geochemistry of the granitoid rocks and their minerals from Lixa do Alvão-Alfarela de Jales-Tourencinho (Vila Pouca de Aguiar, northern Portugal). Chemical Geology 89, 305327.
Neiva, A.M.R., Neiva, J.M.C. \& Silva, M.M.V.G. 1990. Geochemistry of gold quartz vein walls from Jales (northern Portugal). Chemical Geology 82, 217-251.

Neves, L.J.P.F. 1991. Caracterização isotópica ${ }^{18} \mathrm{O} /{ }^{16} \mathrm{O}$ dos granitóides da região de Torredeita (Viseu, Portugal central). Memórias, Notícias e Publicações do Museu e Laboratório Mineralógico e Geológico, Universidade de Coimbra 112, 97-108.

Neves, J.P.F. 1997. Trace element content and partitioning between biotite and muscovite of granitic rocks: a study in the Viseu region (Central Portugal). European Journal of Mineralogy 9, 849-857.

Newberry, R.J., McCoy, D.T. \& Brew, D.A. 1995. Plutonic-hosted gold ores in Alaska: igneous vs. metamorphic origins. In: Ishihara, S. \& Czamanske, G.K. (eds.) Proceedings Sapporo International Conference on Mineral Resources of the NW Pacific Rim. Research Geology Special Issue 18, 57-100.

Noronha, F. 1982. Rochas graníticas do triângulo GerêsBarroso-Cabreira. Suas relações com mineralizações em Sn e W-Mo. Publicações do Museu e Laboratório Mineralógico e Geológico, Faculdade de Ciências, Universidade do Porto 93, 1-39.

Priem, H.N.A. \& Tex, E. den 1984. Tracing crustal evolution in the NW Iberian Peninsula through the Rb-Sr and U-Pb systematics of Palaeozoic granitoids: a review. Physics of the Earth and Planetary Interiors 35, 121-130.

Ramos, J.M.F. 1998. Mineralizações de metais raros de Seixo Amarelo-Gonçalo (Guarda). Contribuição para o seu conhecimento. Unpublished Ph.D. thesis, University of Lisbon. 659 p.

Ribeiro, A., Conde, L. \& Carvalho, D. 1974. Relatório da visita efectuada às Minas de Argemela. Relatório interno da DGGM. Lisboa, Serviço de Fonte Mineiro, 5 p.

Roger, G., Derré, C., Boissavy-Vinau, M., Treuil, M., Jaffrezic, H. \& Kosakevitch, A. 1980. Processus géochimiques de concentration liés à l'évolution de magmas granitiques - Application aux filons à étain et tungstène du Massif Central et du Portugal-Nord. A.T.P., Centre Nuclear Recherche Scientifique (C.N.R.S.), Rapport Final 28.38. 254 p.

Schwartz, M.O. \& Askury, A.K. 1989. Geologic, geochemical and fluid inclusion studies of the tin granites from the Bujang Melaka Pluton, Kinta Valley, Malaysia. Economic Geology 84, 751-779.

Silva, M.M.V.G. 1995. Mineralogia, petrologia e geoquímica de encraves de rochas graníticas de algumas regiões portuguesas. Unpublished Ph.D. thesis, University of Coimbra. 288 p.

Silva, M.M.V.G. \& Neiva, A.M.R. 1990. Geochemistry of the granites and their minerals from Paredes da BeiraPenedono, northern Portugal. Chemical Geology 85, 147-170.

Silva, M.M.V.G. \& Neiva, A.M.R. 1997. Geochemistry of granites and their minerals from Oporto-Gaia area, northern Portugal. Second International Symposium on Granites and Associated Mineralizations. Extended Abstract, p. 157. 
Silva, M.M.V.G. \& Neiva, A.M.R. 2000. Geochemistry of Hercynian peraluminous granites and their minerals from Carregal do Sal-Nelas-Lagares da Beira area, central Portugal. Chemie der Erde 59, 329-349.

Silva, M.M.V.G., Neiva, A.M.R. \& Whitehouse, M.J. 2000. Geochemistry of enclaves and host granites from Nelas area, central Portugal. Lithos 50, 153-170.

Snee, L.W., Sutter, J.F. \& Kelly, W.C. 1988. Thermochronology of economic mineral deposits: dating the stages of mineralization at Panasqueira, Portugal, by high-precision ${ }^{40} \mathrm{Ar} /{ }^{39} \mathrm{Ar}$ ages spectrum techniques on muscovite. Economic Geology 83, 335-354.

Solomon, M.S., Groves, D. \& Jaques, A.L. 1994. The geology and origin of Australia's mineral deposits. Oxford: Clarendon Press. 951 p.

Thompson, J.F.H., Sillitoe, R.H., Baker, T., Lang, J.R. \& Mortensen, J.K. 1999. Intrusion-related gold deposits associated with tungsten-tin provinces. Mineralium Deposita 34, 323-334.

Tischendorf, G. 1974. Metallization associated with acid magmatism. Symposium MAWAM 1, 206-209. Geological Survey of Czechoslovakia, Prague.

Whalen, J.B., Currie, K.L. \& Chappell, B.W. 1987. A-type granites: geochemical characteristics, discrimination and petrogenesis. Contributions to Mineralogy and Petrology $95,407-419$. 